\title{
Recent changes to the hydrological cycle of an Arctic basin at the tundra-taiga transition
}

\author{
Sebastian A. Krogh and John W. Pomeroy \\ Centre for Hydrology, University of Saskatchewan, 121 Research Dr., Saskatoon, SK S7N 1K2, Canada \\ Correspondence: Sebastian A. Krogh (seba.krogh@usask.ca)
}

Received: 7 March 2018 - Discussion started: 21 March 2018

Revised: 3 July 2018 - Accepted: 5 July 2018 - Published: 26 July 2018

\begin{abstract}
The impact of transient changes in climate and vegetation on the hydrology of small Arctic headwater basins has not been investigated before, particularly in the tundrataiga transition region. This study uses weather and land cover observations and a hydrological model suitable for cold regions to investigate historical changes in modelled hydrological processes driving the streamflow response of a small Arctic basin at the treeline. The physical processes found in this environment and explicit changes in vegetation extent and density were simulated and validated against observations of streamflow discharge, snow water equivalent and active layer thickness. Mean air temperature and all-wave irradiance have increased by $3.7^{\circ} \mathrm{C}$ and $8.4 \mathrm{~W} \mathrm{~m}^{-2}$, respectively, while precipitation has decreased $48 \mathrm{~mm}(10 \%)$ since 1960. Two modelling scenarios were created to separate the effects of changing climate and vegetation on hydrological processes. Results show that over 1960-2016 most hydrological changes were driven by climate changes, such as decreasing snowfall, evapotranspiration, deepening active layer thickness, earlier snow cover depletion and diminishing annual sublimation and soil moisture. However, changing vegetation has a significant impact on decreasing blowing snow redistribution and sublimation, counteracting the impact of decreasing precipitation on streamflow, demonstrating the importance of including transient changes in vegetation in longterm hydrological studies. Streamflow dropped by $38 \mathrm{~mm}$ as a response to the $48 \mathrm{~mm}$ decrease in precipitation, suggesting a small degree of hydrological resiliency. These results represent the first detailed estimate of hydrological changes occurring in small Arctic basins, and can be used as a reference to inform other studies of Arctic climate change impacts.
\end{abstract}

\section{Introduction}

Rapid warming in the Arctic (Hansen et al., 2010; Przybylak et al., 2010; Wanishsakpong et al., 2016) has produced significant environmental changes (Hinzman et al., 2005), such as decreasing snow cover duration (Brown et al., 2010) and permafrost thaw (Liljedahl et al., 2016). A reduced snow cover period can result in smaller and slower snowmelt, larger evapotranspiration losses and reduced sublimation losses from headwater basins in cold regions (Pomeroy et al., 2015; Rasouli et al., 2015). Permafrost thaw can impact regional and local hydrology by increasing surface and subsurface connectivity and baseflow (Connon et al., 2014; Liljedahl et al., 2016; Walvoord and Kurylyk, 2016). Increases in vegetation cover and density have been observed and are especially pronounced near the tundra-taiga ecozone transition (Lantz et al., 2013; Myers-Smith et al., 2011; Sturm et al., 2001; Tape et al., 2006; Xu et al., 2013); however, the impact on the hydrology of these transition Arctic basins is poorly understood. These environmental changes will likely continue in the future, representing challenges for water resources managers and engineers throughout the Arctic.

Precipitation trends over the Arctic are highly uncertain due to a sparse monitoring network (Serreze et al., 2003) and difficulties in measuring snowfall in windswept environments (Goodison et al., 1998; Pan et al., 2016). Nevertheless, positive and negative trends have been calculated for the largest Arctic river basins (Walsh, 2005, Table 6.12) and throughout the Arctic (Whitfield et al., 2004). Over northern Canada, an overall increasing trend in annual precipitation has been observed (DeBeer et al., 2016; Vincent et al., 2015); however, there is great spatial variability and uncertainty due to the low-density observational network (Milewska and Hogg, 2001). Mean annual temperatures in northwestern 
Canada have increased more than anywhere else in Canada by roughly $3-3.5^{\circ} \mathrm{C}$ between 1948 and 2012 (Vincent et al., 2015); moreover, mean winter temperatures show the largest increase of up to $6.5^{\circ} \mathrm{C}$ (DeBeer et al., 2016).

Arctic vegetation has changed in response to warmer temperatures (Hinzman et al., 2005; Martin et al., 2017; MyersSmith and Hik, 2018). The tundra-taiga treeline in Alaska, USA, has advanced from 80 to $100 \mathrm{~m}$ in the last 200 years (Suarez et al., 1999). Payette and Filion (1985) studied white spruce (picea glauca) expansion into northern Quebec, Canada, and found that the treeline has not changed substantially over the past centuries; however, below the treeline, its density has increased. On the other hand, both shrub coverage and density have increased in the Arctic. Lantz et al. (2013) reported that between 1972 and 2004, shrub density and cover have increased substantially in the upland tundra east of the Mackenzie River delta of northwestern Canada. Similar results were found by Tape et al. (2006) in northern Alaska and pan-Arctic. Overall, these previous studies observed that the Arctic treeline has not undergone a substantial change over the last century, but that shrub expansion is ubiquitous near the Arctic treeline in North America. Wildfires can rapidly modify vegetation cover and are important to nutrient cycling, biodiversity and the control of pathogens and pests (Bond and Keeley, 2005). Warmer temperatures and longer dry seasons are increasing vulnerability to wildfire (Romero-Lankao et al., 2014), resulting in increased frequency and duration of wildfires since the mid-1980s (Westerling et al., 2006; Williamson et al., 2009). Changes in vegetation are important, as they have been shown to control snow redistribution (Ellis et al., 2013; Essery and Pomeroy, 2004; Ménard et al., 2014; Pomeroy and Brun, 2001) and energy fluxes (Ménard et al., 2012; Pomeroy et al., 2006; Sturm et al., 2000).

Many studies have looked at observed changes in large northward-flowing river basins. There is an increase in annual discharge from large river basins to the Arctic Ocean (McClelland et al., 2006; Overeem and Syvitski, 2010; Peterson et al., 2002; Rood et al., 2017; Yang et al., 2002), a decrease in river ice thickness (Peterson et al., 2002) and earlier river/lake ice break-up dates (Janowicz, 2010; Prowse et al., 2011). However, most of these large river basins have their headwaters and primary zones of runoff generation well below the Arctic Circle, and therefore are not necessarily representative of changes in the Arctic hydrological cycle. As limited observations are available in the Arctic, model outputs have also been used to investigate change. Increasing trends were found in simulated monthly evapotranspiration and streamflow for the Mackenzie River basin, Canada (Yip et al., 2012), and in simulated Arctic soil temperature and active layer thickness (Oelke et al., 2004), whereas decreasing trends were found in simulated Arctic snow accumulation and snow cover duration (Liston and Hiemstra, 2011). López-Moreno et al. (2016) analyzed simulated historical trends in the snow processes of a small basin above the Arctic treeline in Svalbard, using a physically based hydrological model that accounted for blowing snow redistribution and energy balance snowmelt. They found that simulated snow accumulation, snow-covered season and days with snowfall decreased significantly, driven by a significant increase in air temperature. No study has looked at changes in Arctic hydrological processes from headwater basins that originate near the Arctic treeline, nor has the relationship between changes in hydrological processes due to climate and vegetation change been investigated.

Using hydrological models to simulate the hydrological cycle can compensate for an inability to observe it due to ungauged basins (Pomeroy et al., 2013b) and decline in the coverage of Arctic monitoring networks (Laudon et al., 2017). Previous studies acknowledged the need for robust hydrological models suitable for cold regions to simulate Arctic hydrology (Quinton and Carey, 2008; Woo et al., 2008), particularly due to the complex interaction between subsurface and surface mass and energy fluxes (Kane et al., 1991; Krogh et al., 2017; Zhang et al., 2000). Physical processes that must be accounted for include snow accumulation and melt (Marsh et al., 2010), snow interception and sublimation from forest canopies (Hedstrom and Pomeroy, 1998; Pomeroy et al., 1998; Schmidt and Gluns, 1991), blowing snow sublimation and redistribution (Pomeroy et al., 1997; Schmidt, 1982), evapotranspiration (Wessel and Rouse, 1994), infiltration into frozen and unfrozen soils (Gray et al., 2001; Kane, 1980; Kane and Stein, 1983), water flow through snowpack (Colbeck, 1972; Marsh and Woo, 1984a, b), ground freeze and thaw (Juminikis, 1977), surface and subsurface flow (Quinton and Gray, 2001; Quinton and Marsh, 1999), and groundwater (Cederstrom et al., 1953) and streamflow routing (Woo and Sauriol, 1980). The Cold Regions Hydrological Model (CRHM) platform was used to create the Arctic Hydrology Model (AHM) configuration (CRHM-AHM) by Krogh et al. (2017). This spatially distributed and physically based model includes the key hydrological processes found at the Arctic treeline, such as blowing snow, snow and rain interception, sublimation, snowmelt, flow through snow, infiltration to frozen and unfrozen soils, evapotranspiration, runoff as overland flow and subsurface flow through organic terrain, frozen ground dynamics including active layer thaw and groundwater flow and streamflow routing. CRHM-AHM was shown to properly represent the winter and summer hydrology of this environment with minimal calibration of some uncertain routing and storage parameters (Krogh et al., 2017). A great advantage of this model is its flexibility and potential to be adapted for the simulation of other Arctic basins.

The aim of this study is to understand, diagnose and quantify the long-term hydrological changes of a small Arctic treeline basin, including transient changes in vegetations and climate over a multidecadal period, using the CRHM-AHM model. The study addresses the following research questions: what hydrological changes are caused by individual transient 


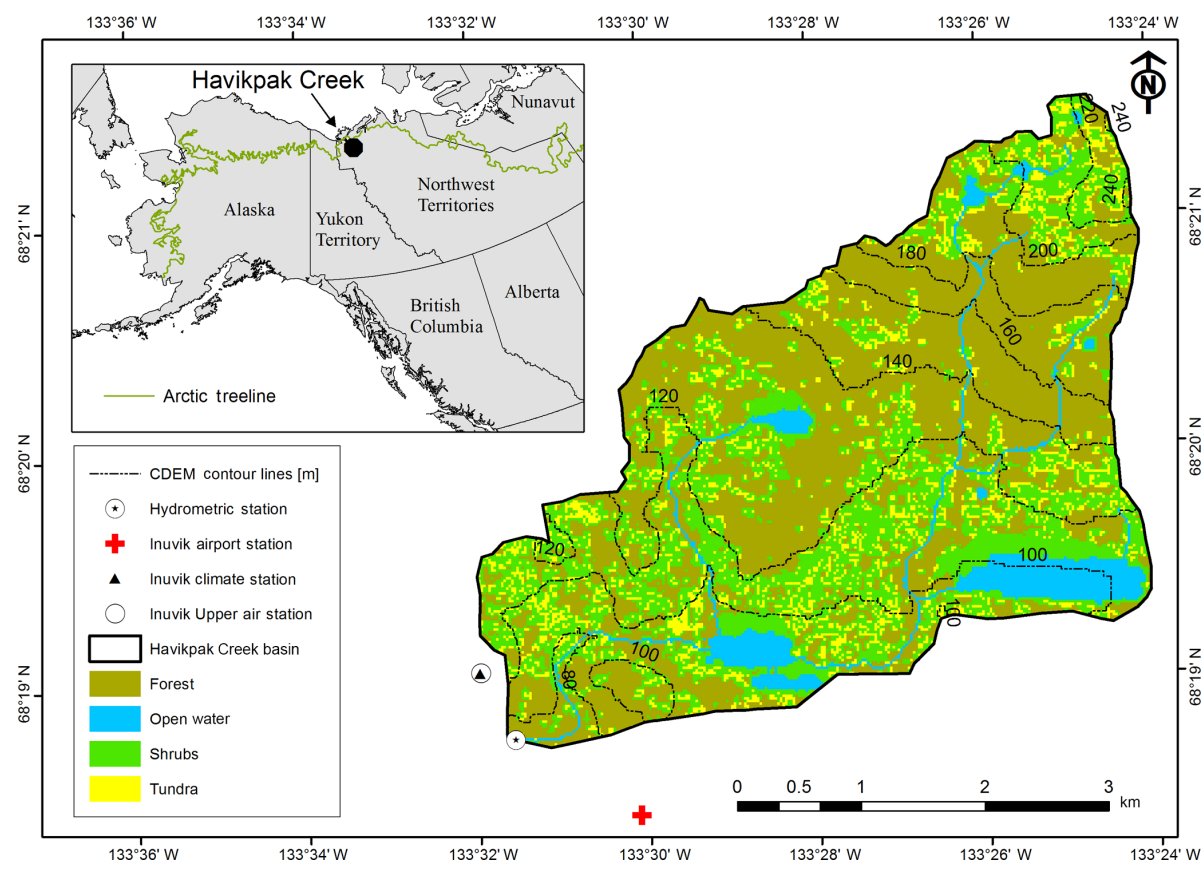

Figure 1. Havikpak Creek basin including elevation contour lines (based on the Canadian Digital Elevation Model - $20 \mathrm{~m}$ ), the location of weather and hydrometric stations and the 1992 landcover map based on Krogh et al. (2017). Inset plot shows the location of the study site within North America and the approximate location of the Arctic treeline.

changes in climate and vegetation? What are the coupled hydrological impacts of changes in climate and vegetation? Does transient vegetation change enhance or dampen climate change? Does Arctic hydrology show resiliency to the impacts of climate change? To address these questions, the study compares three observation-driven hydrological modelling scenarios: (1) observed climate change and constant vegetation cover, (2) observed changes in vegetation with climate held constant and (3) observed changes in climate and vegetation.

\section{Study site}

Havikpak Creek (HPC), with an area of $16.4 \mathrm{~km}^{2}$, is located east of Inuvik, Northwest Territories, Canada (Fig. 1), near the tundra-taiga transition. HPC is in the continuous permafrost region, with an elevation rising from $60 \mathrm{~m}$ a.s.l. in the southwest to $240 \mathrm{~m}$ a.s.l. in the northeast. This basin was selected as it has a history of process-based hydrological studies, which provides a good understanding of dominating hydrological processes, has long-term meteorological records and has been part of important international initiatives, such as the Mackenzie GEWEX study (MAGS). HPC is also within the domain of the NASA Arctic-Boreal Vulnerability Experiment (ABoVE; https://above.nasa.gov/, last access: 12 July 2018), which aims to better understand the vulnerability and resiliency of Arctic boreal ecosystems, and therefore, its great relevance.
Estimates of mean annual temperature and precipitation between 1981 and 2010 at Inuvik, using observations at the Meteorological Service of Canada weather station (Climate ID: 2202570) by Environment and Climate Change Canada (ECCC), are $-8.2^{\circ} \mathrm{C}$ and $240.6 \mathrm{~mm}$, respectively (http://climate.weather.gc.ca/climate_normals/index _ e.html, last access: 12 July 2018). However, Krogh et al. (2017) showed that the corrected mean annual precipitation between 1980 and 2009 at Inuvik, based on the Adjusted and Homogenized Canadian Climate Dataset (AHCCD; Mekis and Vincent, 2011) and additional local weather stations, is $327 \mathrm{~mm}$. Differences between precipitation estimates published by ECCC and Krogh et al. (2017) are due to Krogh's use of the AHCCD dataset with its corrections of snowfall wind undercatch and trace events. Such large adjustments to corrected precipitation are not uncommon at high latitudes in Canada and can influence trend detection (Pomeroy and Goodison, 1997). Using corrected data, $59 \%$ of the mean annual precipitation is snowfall; however, peak monthly precipitation occurs as rainfall in August ( $\sim 45 \mathrm{~mm}$; Krogh et al., 2017). Snow accumulation typically starts in mid-September, with peak accumulation at the end of April or beginning of May, and snowmelt lasts until early to mid-June (Krogh et al., 2017). The streamflow regime of Havikpak Creek is measured by the Water Survey of Canada and is characterized by a rapid increase due to snowmelt in May and June, during which the annual peak streamflow occurs $\left(1-4 \mathrm{~m}^{3} \mathrm{~s}^{-1}\right)$, followed by decreasing streamflow interrupted by sporadic summer peaks due to intense rainfall 
(Krogh et al., 2017). No streamflow was observed during winter.

In 1992, HPC was predominantly covered by black spruce (Picea mariana) forest $(50.0 \%)$ followed by alder shrubs $(31.7 \%)$, short grass, moss and lichen tundra $(11.6 \%)$ and open water (6.7\%) (Krogh et al., 2017). However, as shrubs colonize the tundra (Lantz et al., 2013) these percentages have changed. No changes in forest cover have been reported, though investigations into this are understood to be underway. A slight "greening" of the region has been detected through Normalized Difference Vegetation Index (NDVI) analysis of Landsat satellite imagery, but is not attributed to specific vegetation changes (Ju and Masek, 2016). Soils in HPC are characterized by a top layer (roughly $10 \mathrm{~cm}$ ) of decomposed and highly porous organic matter (upper peat), followed by a highly decomposed and denser organic layer underneath (lower peat), estimated to be between 20 and $50 \mathrm{~cm}$ thick on top of a mineral soil layer (Krogh et al., 2017). No soil changes have been reported. For a detailed description regarding HPC climate, land cover, soils, weather and hydrometric stations, the reader is referred to Krogh et al. (2017).

\section{Data}

Reconstructed weather time series used in this study are based on a combination of observations, adjusted and homogenized time series from the AHCCD dataset (station ID: 2202578; Mekis and Vincent, 2011), ERA-40 (Uppala et al., 2005) and ERA-Interim (Dee et al., 2011) reanalysis over the period 1960-2016. Reanalysis data have been used in the past to complement meteorological observations for hydrological studies (e.g. Krogh et al., 2015). Six-hourly timestep variables were used to drive CRHM-AHM (see Sect. 4.1): precipitation, air temperature, relative humidity, wind speed and incoming short- and long-wave radiation (Fig. 2). Data used for model validation consist of observed daily streamflow (Sect. 5.2). A reconstructed vegetation cover map, topographic information and a site visit informed the spatial model configuration.

\subsection{Temperature}

Daily minimum, maximum and mean temperatures from the AHCCD dataset are available from 1957 to 2014. Hourly temperature is available from Inuvik Airport from 1980 to 2016 and from Inuvik Climate from 2003 to 2016. To generate a uniform time series of hourly temperature, the following steps were followed: (1) minimum and maximum from the AHCCD dataset (1957-2014) were used to generate hourly temperature by fitting a sinusoidal function, as presented by Chow and Levermore (2007; Eq. 6); (2) hourly temperature measured by the Inuvik Airport station (1980-2016) was used to correct hourly temperature from the AHCCD dataset (1960-1980) through a linear re- gression model $\left(R^{2}=0.97\right)$; and (3) Inuvik Airport hourly data were used for the period 1980-2016.

\subsection{Precipitation}

Daily precipitation from the AHCCD dataset for the period 1960-2006 is available; however, after 1994, several gaps were found. Precipitation measurements from the AHCCD at Inuvik were all made by observers and are considered reliable. After 1994, automatic systems were sometimes used to improve the corrections from snow ruler measurements (Mekis and Vincent, 2011). For measurements from 1994 to 2007, a combination of AHCCD and the local ECCC automatic weather stations Inuvik Climate, Inuvik Upper Air and Inuvik Airport (Fig. 1) was used. From 2007 onward, the Inuvik Climate station (automatic) was the only station recording precipitation. The automatic station snowfall data were corrected for wind undercatch using the expression presented by Smith (2008) for the Alter-shielded Geonor solid precipitation gauge. A specific snowfall correction had to be applied between October and March for the water years 2010 to 2012, as winter precipitation from the Inuvik Climate precipitation gauge was not found to be credible. Observed snow accumulation (snow water equivalent, SWE) in sheltered sites and observed streamflow suggest that snowfall measured during these years was grossly underestimated. The ratios between SWE measured at the end of winter (1 April) and cumulative snowfall in 20112013 were 2.6, 1.7 and 2.5, respectively (after wind undercatch corrections); the ratios associated with the other years with both SWE and streamflow data (2003 to 2015) show values around 1. A solution to this problem was proposed and implemented by Pomeroy et al. (1997) at a nearby location (Trail Valley Creek) and consists of estimating "true" winter snowfall from late season snow surveys in a small glade within a forest. Pomeroy et al. (1997) argued that the windand sun-sheltered and cold conditions of the site ensured that the snow on the ground in the glade was not redistributed, sublimated or melted, and was therefore equal to the cumulative snowfall. SWE measurements used in this study have the same conditions as those found by Pomeroy et al. (1997) (i.e. sheltered site with mild winds and cold environment), and therefore, their approach was used to estimate true snowfall.

To disaggregate daily into hourly precipitation, the same procedure used in Krogh et al. (2017) was followed. This employs the microcanonical cascade model presented by Güntner et al. (2001). This disaggregation technique assumes that the probability distribution function of the weights factors, defined as the ratio between a lower and upper disaggregation level (e.g. 12 and $24 \mathrm{~h}$ ), from the different disaggregation levels (e.g. 3, 6, 12 and $24 \mathrm{~h}$ ) is constant, and it was obtained aggregating hourly precipitation records. The reader is referred to Güntner et al. (2001) and Krogh et al. (2017) for 


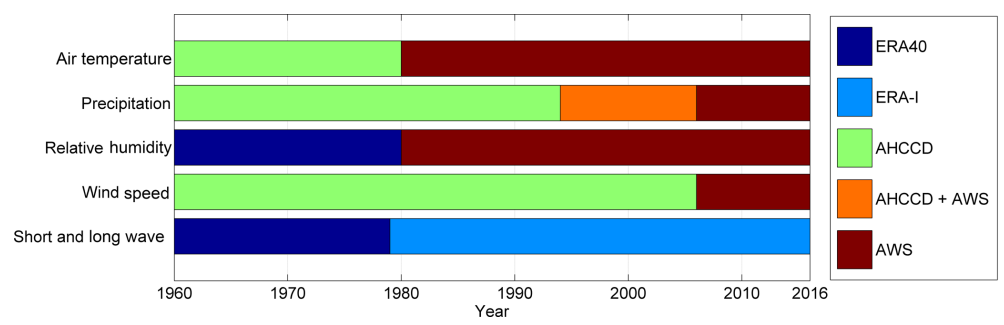

Figure 2. Data source for each of the weather variables during the period 1960-2016. AWS: automatic weather station. AHCCD: Adjusted and Homogenized Canadian Climate Data. ERA-I: ERA-Interim.

further details of this methodology and the particular application to the Inuvik precipitation dataset, respectively.

\subsection{Relative humidity}

Relative humidity was calculated using 6-hourly air temperature and dew point temperature from ERA- 40 for the period 1960-2002, using the expression from Lawrence (2005). A linear interpolation was then used to calculate hourly values. ERA-40 values from 1960 to 1980 were corrected using a linear relationship for the period 1980-2002 between hourly ERA-40 and measured relative humidity at Inuvik Airport $\left(R^{2}=0.7\right)$. Finally, hourly corrected values from ERA-40 were used from 1960 to 1980 and observed values from 1980 to 2016 . Relative humidity was not permitted to exceed $100 \%$ in this estimation.

\subsection{Wind speed}

Hourly $10 \mathrm{~m}$ height wind speed from the AHCCD dataset and Inuvik Airport station for the period 1960-2006 and 20062016 were used, respectively.

\subsection{Short- and long-wave irradiance}

Short- and long-wave irradiance were not measured and so were obtained from the ERA-40 (1960-2002) and ERAInterim (1979-2016) atmospheric model reanalyses at $3 \mathrm{~h}$ time steps. A linear interpolation was used to obtain hourly values for each dataset. The ERA-Interim is a more advanced reanalysis, and has shown small biases in Arctic environments (Lindsay et al., 2014), so it was used as true incoming radiation and ERA-40 outputs were corrected to match the ERA-Interim. The overlapping period between ERA40 and ERA-Interim is 1979-2002 (23 years); this period was used to bias-correct ERA-40 over 1960-1979 using the quantile mapping technique. Quantile mapping is a statistical approach used in hydrometeorological studies to biascorrect weather-variable time series from atmospheric models against measurements (e.g. Boé et al., 2007); it corrects each quantile by matching the empirical cumulative distribution functions. The irradiance time series created uses the bias-corrected ERA-40 for 1960-1979 and ERA-I for 19792016.

\subsection{Streamflow}

Daily streamflow discharge at HPC was observed and estimated at the hydrometric station (ID: 10LC017) by the ECCC Water Survey of Canada (WSC). This station is downstream from the Havikpak Creek crossing with the Dempster Highway and its drainage area defines the basin for modelling purposes. Discharge estimates for this station start in 1995 and are available to 2015; however, the year 2005 is not available. Measuring small stream discharge in the Arctic is challenging and problems or uncertainties associated with the estimates are acknowledged in the metadata provided by the ECCC through the Environment Canada Data Explorer. The main issues in the hydrometric record are due to the presence of ice and snow in the cross section during snowmelt including peak streamflows, as ice and snow cause substantial variability in rating curves and make streamflow and water stage measurements quite difficult.

\subsection{Vegetation cover and shrub density}

The vegetation cover map and shrub density used in this study are based on the map and values presented by Krogh et al. (2017) from 1992, and the changing shrub cover and density rates presented by Lantz et al. (2013) for a larger region that includes Havikpak Creek. Lantz et al. (2013) showed that between 1972 and 2004 (32 years) shrub cover increased by $15 \%( \pm 3.6)$ and shrub density increased by $68 \%( \pm 24.1)$ on average. These average rates were recalculated to an annual basis, resulting in rates of $0.47 \% \mathrm{yr}^{-1}$ and $2.13 \% \mathrm{yr}^{-1}$ for shrub cover and density increases, respectively. To reconstruct times series of vegetation cover and shrub density, the average rates presented by Lantz et al. (2013) were used to linearly extrapolate forwards and backwards from the values used in Krogh et al. (2017), creating a time series of vegetation cover and shrub density from 1960 to 2016. As shrubs colonize the tundra, any increase in shrub cover is compensated by a decrease in the tundra cover, maintaining a constant drainage area. It is unclear when shrub expansion in the Arctic began (Tape et al., 2006), mostly because satellite images started to be available in the 1970s, limiting our understanding of vegetation changes to the 1970s onward. 
The HPC forest was held constant in this study, as there are no published studies quantifying forest cover or density change in the region. However, we acknowledge that there are ongoing investigations about changes in forest structure in the region. Greening of the NDVI is not directly attributable to forest change and could be due to documented shrubification. There are no recorded wildfires in Havikpak Creek during the study period as it is close to the airport and so fire suppression by local authorities is very effective.

\section{Methodology}

\subsection{Hydrological modelling}

The Cold Regions Hydrological Modelling platform (CRHM) is a process-based and spatially distributed hydrological modelling system with a flexible modular structure that allows the selection of different hydrological processes from an extensive library to create a customized hydrological model. Most of the modules available in the CRHM have a strong physical basis, with particular emphasis on, but not restricted to, cold region processes. The CRHM Arctic Hydrology Model configuration (CRHMAHM) developed and verified by Krogh et al. (2017) includes the following hydrological processes: forest canopy interception, sublimation and evaporation, snow melt and snow accumulation, evapotranspiration, blowing snow redistribution and sublimation, ground freeze and thaw, water flow through snowpack and organic terrain, infiltration into frozen and unfrozen soils, soil moisture storage and flow, surface water flow and streamflow routing. The model was run over the period from October 1960 to October 2016 on an hourly basis. A 4-year spin-up period was used by repeating the years 1960-1963.

CRHM uses hydrological response units (HRUs; Flügel, 1995) as the spatial unit of discretization for application of the continuity equation to compute mass and energy fluxes. In the CRHM-AHM, the HPC basin was discretized into 11 HRUs initially classified by land cover: tundra, sparse shrubs, close shrubs, taiga, forest, wetland and open water. To include the different near-surface wind regimes observed by Pomeroy and Marsh (1996) over the basin, the tundra and sparse shrub HRUs were each split into an upper and lower HRU to reflect stronger wind regimes in the hilly, higher elevation, upper basin. To simulate the longlasting snow drifts found in steep gullies and around small lakes, a gully/drift HRU was created following the criteria from Pomeroy and Marsh (1996). The physiographic characteristics of the HRUs used in the CRHM-AHM applied in HPC are as in Krogh et al. (2017, Table 2).

The parameterization of the CRHM-AHM followed the deduction-induction-abduction approach (DIA; Pomeroy et al., 2013a) by first using field information (e.g. slope and vegetation cover), parameters from previous studies in
Havikpak Creek and other research basins with similar hydrological regimes and physical processes, and then calibrating a few subsurface and surface hydraulic and storage parameters, for which there was poor understanding, against streamflow. The CRHM-AHM represents the snow, permafrost and streamflow regimes of Havikpak Creek well when compared to observations (Krogh et al., 2017).

\subsection{Modelling scenarios}

Three modelling scenarios representing only historical climate change $(\Delta \mathrm{C})$, only historical vegetation change $(\Delta \mathrm{V})$ and both historical climate and vegetation change $(\Delta \mathrm{CV})$ were developed to examine the hydrological impacts of changes in HPC since 1960 and are described below.

\subsubsection{Model scenario $1(\Delta C)$ : changing climate and constant vegetation}

This scenario uses the reconstructed climate time series presented in Sect. 3 for the period 1960-2016 with a constant vegetation cover and density representative of the year 1988, which is the average vegetation cover of the modelling period.

\subsubsection{Model scenario $2(\Delta V)$ : constant climate and changing vegetation}

This scenario uses a "normal" water year in terms of precipitation and temperature to generate the stationary climate. The mean annual (October to September) precipitation and temperature for the period October 1960 to October 2015 is $332 \mathrm{~mm}$ and $-8.2^{\circ} \mathrm{C}$, respectively. To select a normal water year, the residual between mean annual precipitation and air temperature for the entire period (1960-2016) was calculated to select the water year with the minimum combined residual. This was the water year 1962-1963 as the mean annual precipitation and temperature were $327 \mathrm{~mm}$ and $-8.0^{\circ} \mathrm{C}$, respectively. Seasonal representability was also investigated by looking at the standard deviation of the absolute difference between mean monthly values and the 1962-1963 water year monthly values, resulting in $10 \mathrm{~mm}$ and $1.1^{\circ} \mathrm{C}$ for precipitation and temperature, respectively, suggesting that 1962-1963 is a good representation of the monthly variations. Given the importance of snowmelt to streamflow in the Arctic, winter precipitation (October to April) was compared; for 1962-1963 it was $194 \mathrm{~mm}$, and on average over the period it was $166 \mathrm{~mm}$, suggesting that this normal year is somewhat snowier than average.

This scenario includes transient changes in vegetation using the vegetation cover and density time series as described in Sect. 3.7. The increase in shrub cover was proportionally applied to the upper and lower sparse shrub HRUs, whereas the area of the wetland and gully/drift HRUs was kept constant as their delineation does not depend on the shrubcovered area, but on wetland and topographic criteria (Krogh 


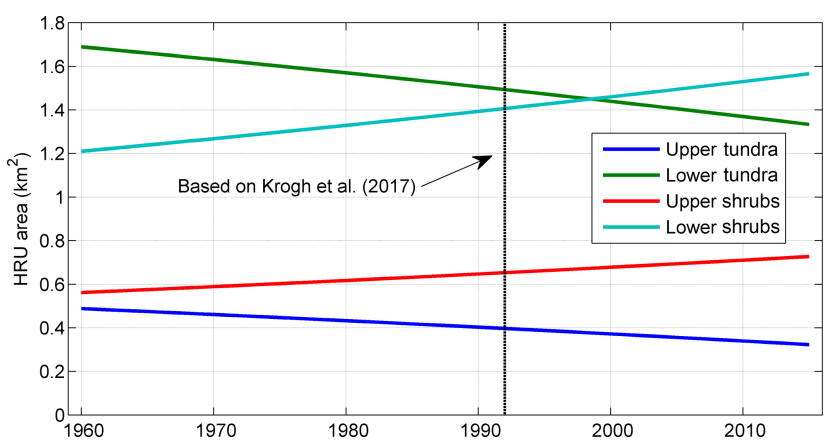

Figure 3. Annual changes in the tundra and shrub HRUs area used in the CRHM-AHM model.

et al., 2017). To implement this transient change, the model was run annually and the shrub cover and density parameters were incremented every 1 November. Figure 3 presents the change in area for the sparse shrubs and tundra HRUs during the modelling period, and the year 1992, which is the vegetation cover used by Krogh et al. (2017).

\subsubsection{Model scenario $3(\Delta \mathrm{CV})$ : changing climate and vegetation}

This scenario includes changing climate and transient vegetation as presented for the scenarios $\Delta \mathrm{C}$ and $\Delta \mathrm{V}$, and represents the hydrology of Havikpak Creek as realistically as possible.

\subsubsection{Transferring initial conditions}

In $\Delta \mathrm{V}$ and $\Delta \mathrm{CV}$, the CRHM-AHM was run annually to permit the updating of vegetation parameters at the end of the hydrological year; therefore, final conditions from one year needed to be transferred to the next, and updated with the change in the HRU area. To transfer the initial condition of a given state variable " $S$ " (e.g. volumetric soil moisture or snow water equivalent) from the year $(t)$ and HRU1 $\left(S_{1}^{t}\right)$ to the next year and HRU2 $\left(S_{2}^{t+1}\right)$, the following relationship can be obtained through mass conservation, assuming that area is transferred from HRU1 (tundra) to HRU2 (sparse shrub):

$S_{2}^{t+1}=\frac{A_{2}^{t} \cdot S_{2}^{t}+\left(A_{1}^{t+1}-A_{1}^{t}\right) \cdot S_{1}^{t}}{A_{2}^{t+1}}$

$S_{1}^{t+1}=S_{1}^{t}$.

Equations (1) and (2) were used to pass on soil moisture, soil recharge and snow water equivalent state variables from year to year as HRU areas changed.

\subsection{Trend and change point analysis}

The non-parametric Mann-Kendall test (Kendall, 1975; Mann, 1945) was used to perform trend analysis on simulated hydrological variables and observed weather data using a significance threshold of $p \leq 0.05$. The Mann-Kendall test has been extensively used to analyze linear trends in hydrological datasets (e.g. Burn and Hag Elnur, 2002; Hamed, 2008; Yip et al., 2012), proving better results than other methods (Hess et al., 2001). As recommended by Hamed and Rao (1998) time series autocorrelation was removed before performing the Mann-Kendall test to eliminate the detection of false trends. The trend of slopes was calculated using Sen (1968) based on Kendall's rank correlation $\tau$. Variables presented as a percentage of annual precipitation (i.e. rainfall and snowfall ratios) were $\log$-transformed $(y=\log (x /(1-x))$ first. Single change points in the time series were detected using the R-Package "changepoint" version 2.2.2 (Killick et al., 2016) based upon Hinkley (1970). These two techniques (Mann-Kendall and change point analysis) were used together as they complement each other and can be used to look at changes in different ways. For example, the detection of significant trends using the Mann-Kendall test depends on the arbitrary significance threshold, whereas the change point analysis assumes that the time series is normally distributed. Although both techniques have their own limitations they are both equally legitimate, resulting in potentially two different results, such as a time series with no statistically significant trend but a detectable mean change point.

\subsection{Teleconnections}

To determine the influence of climatological teleconnections on hydrometeorological conditions in HPC, basin-scale mass fluxes were correlated to five climatic indexes representing large-scale circulation features over 1960-2016: (1) Arctic Oscillation (AO; Thompson and Wallace, 1998), (2) North Atlantic Oscillation (NAO; Hurrell et al., 2001), (3) North Pacific Index (NPI; Trenberth and Hurrell, 1994), (4) Southern Oscillation Index (SAO; Rasmusson and Carpenter, 1982) and (5) Pacific Decadal Oscillation (PDO; Mantua and Hare, 2002). These climatic indexes have been used to investigate teleconnections in Arctic and subarctic environments (Bonsal et al., 2006; Déry and Wood, 2004; Serreze et al., 2002). Teleconnections analysis was restricted to $\Delta \mathrm{CV}$, as this scenario fully represents the observed changes in HPC.

\section{Results}

\subsection{Meteorological trends}

Figure 4 shows point changes and trends in seasonal and water year (October to September) precipitation for the period October 1960-October 2016. Seasons were defined based on local hydrology: winter is from October to April when 
Table 1. Changes in precipitation and temperature for the period 1960-2016 and statistically significant trends at the $p \leq 0.05$ significance threshold using the Mann-Kendall test. Changes in precipitation as a percentage with respect to 1960 are also presented.

\begin{tabular}{lcccc}
\hline Period & $\begin{array}{c}\text { Precipitation } \\
(\mathrm{mm})\end{array}$ & $\begin{array}{c}\text { Minimum air } \\
\text { temperature } \\
\left({ }^{\circ} \mathrm{C}\right)\end{array}$ & $\begin{array}{c}\text { Mean air } \\
\text { temperature } \\
\left({ }^{\circ} \mathrm{C}\right)\end{array}$ & $\begin{array}{c}\text { Maximum air } \\
\text { temperature } \\
\left({ }^{\circ} \mathrm{C}\right)\end{array}$ \\
\hline Winter & - & 8.0 & 5.2 & - \\
Spring & $-15.1(27 \%)$ & - & 2.7 & - \\
Summer & - & - & 0.8 & 1.8 \\
Fall & - & - & 1.6 & - \\
\hline Annual & - & 8.0 & 3.7 & 1.8 \\
\hline
\end{tabular}

the snowpack forms and redistributes, spring is May when most snowmelt occurs, summer is from June to August and is a season of rainfall, soil thaw and minimal snowmelt and fall is September when the active layer of the grounds starts to refreeze and precipitation shifts to snowfall. No trends were found for seasonal or annual precipitation, except spring, which had a significant and decreasing trend of $-2.7 \mathrm{~mm} \mathrm{decade}^{-1}$. Conversely to the trend analysis, the change point analysis shows changes in most seasons and annually. Winter, spring and summer precipitation decreases from 187 to $160 \mathrm{~mm}, 25$ to $13 \mathrm{~mm}$ and 146 to $108 \mathrm{~mm}$, respectively, whereas fall precipitation increases from 16 to $34 \mathrm{~mm}$. Annual precipitation decreases from 369 to $321 \mathrm{~mm}$ $(48 \mathrm{~mm})$ in the water year 1972. Analysis of the number of days with precipitation above the thresholds $1,2,5,10$ and $25 \mathrm{~mm} \mathrm{day}^{-1}$ showed a decreasing trend for events greater than 1,2 and $5 \mathrm{~mm} \mathrm{day}^{-1}$ with a slope of $-3.8,-1.7$ and -0.7 days decade ${ }^{-1}$, respectively. There are no changes in measurement methods associated with these changes.

Figure 5 shows seasonal and annual changes points and trends for minimum, maximum and mean daily air temperature. Increasing trends for mean air temperature were found annually and in every season, with the largest positive trend of $0.9^{\circ} \mathrm{C} \mathrm{decade}^{-1}$ in winter. Maximum air temperatures increased significantly annually and in summer, at $0.3{ }^{\circ} \mathrm{C} \mathrm{decade}^{-1}$ in both cases. Winter, spring and fall maximum air temperatures did not show significant trends. Minimum air temperatures increased rapidly annually and in winter, at $1.4{ }^{\circ} \mathrm{Cdecade}^{-1}$ in both cases. Spring, summer and fall minimum annual temperatures did not show significant trends. Change point analysis showed that these trends are reflected by an increase in mean annual temperature during the water year 1992 , from -9.1 to $-7.1^{\circ} \mathrm{C}$. Seasonally, the change point analysis shows warming in all seasons but in summer and fall for minimum and mean temperature, respectively. Table 1 presents the changes in temperature for the period 1960-2016 for variables with statistically significant trends. The $8^{\circ} \mathrm{C}$ increase in annual and winter minimum temperatures and $3.2^{\circ} \mathrm{C}$ increase in annual $\left(5.2^{\circ} \mathrm{C}\right.$ winter $)$ mean
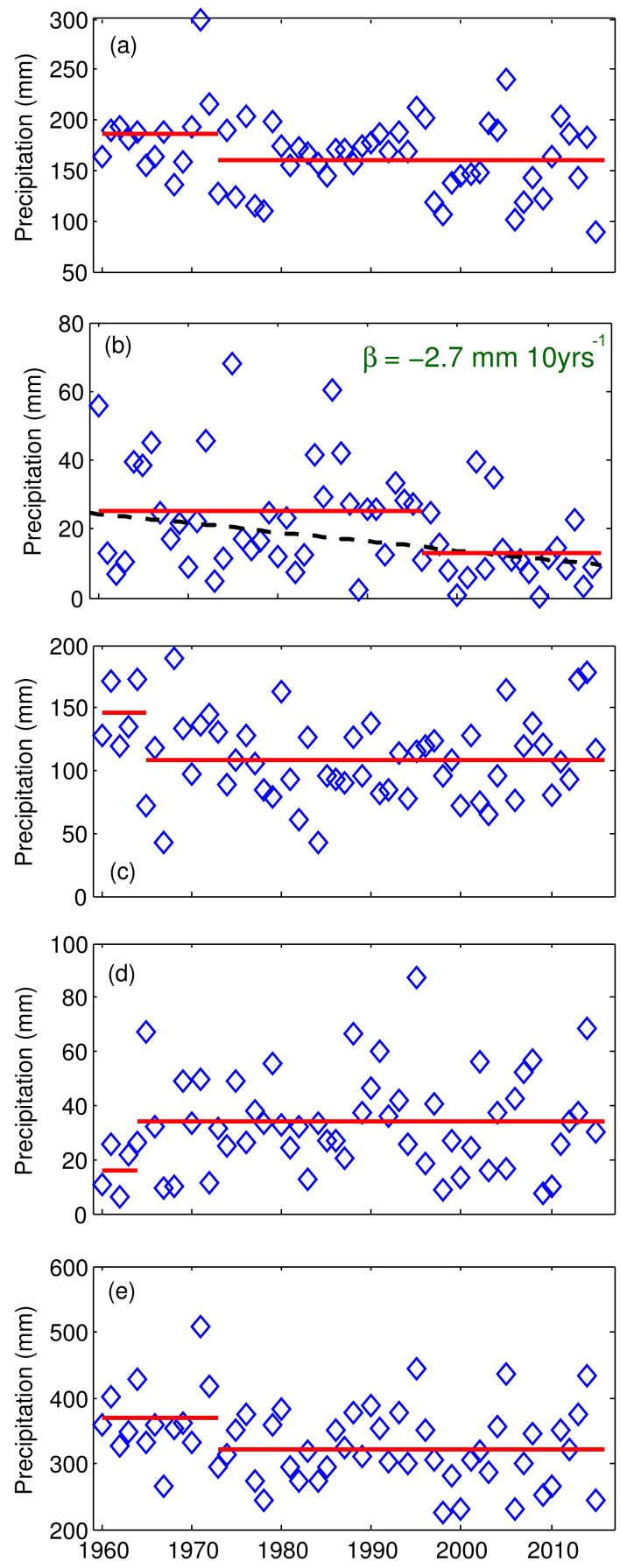

Figure 4. Observed seasonal and annual precipitation for each water year (October-September) from 1960 to 2015. (a) Winter (October-April), (b) spring (May), (c) summer (June-August), (d) fall (September) and (e) annual. The slope $(\beta)$ is shown in mm decade ${ }^{-1}$ for statistically significant trends at the $p \leq 0.05$ significance threshold. The solid red line shows the annual change point. 
temperatures over 56 years are remarkable and amongst the highest recorded on Earth.

Table 2 presents the statistically significant trends for the other meteorological forcing variables used by CRHMAHM at seasonal and annual scales. Mean annual short-wave irradiance has been decreasing by $-1.4 \mathrm{~W} \mathrm{~m}^{-2}$ decade $^{-1}$ driven by decreases in spring and summer, whilst mean annual long-wave irradiance has been increasing by $2.9 \mathrm{~W} \mathrm{~m}^{-2}$ decade $^{-1}$, with greater increases in summer and fall than in winter and spring. Mean annual all-wave irradiance (short- and long-wave irradiance) has been increasing by $1.5 \mathrm{~W} \mathrm{~m}^{-2}$ decade $^{-1}$; however, summer all-wave irradiance has been decreasing by $-2.9 \mathrm{~W} \mathrm{~m}^{-2}$ decade $^{-1}$. Mean annual wind speed did not change and relative humidity has been increasing by $0.8 \%$ decade $^{-1}$. Table 3 shows the change point analysis for the atmospheric variables forcing CRHM-AHM. Mean annual short- and long-wave irradiance have change points in the water year 1969, from 112 to 104 and 230 to $242 \mathrm{~W} \mathrm{~m}^{-2}$, whereas all-wave irradiance has a change point in 1997 , from 344 to $348 \mathrm{~W} \mathrm{~m}^{-2}$. Mean annual relative humidity has a change point in the water 2013 , from 69 to $75 \%$. No change point was found for mean annual wind speed. Three wind speed thresholds representing nonblowing snow $\left(2 \mathrm{~m} \mathrm{~s}^{-1}\right)$, light-drifting $\left(6 \mathrm{~m} \mathrm{~s}^{-1}\right)$ and strong blizzards $\left(12 \mathrm{~m} \mathrm{~s}^{-1}\right)$ were analyzed. Significant decreases in the hours of events larger than 2 and $6 \mathrm{~m} \mathrm{~s}^{-1}$ were found at -71 and -23 events decade ${ }^{-1}$. The number of hourly events with strong blizzards showed no significant trend.

\subsection{Updated CRHM-AHM validation}

The 1995 to 2015 Nash-Sutcliffe Efficiency (NSE) and mean bias were found to be 0.40 and $6 \%$, respectively, suggesting that the model's streamflow performance is consistent with that showed by Krogh et al. (2017), and changing vegetation dynamic parameterization has a small impact on the shortterm model's streamflow performance.

\subsection{Trends comparison between modelling scenarios}

\subsubsection{Sub-basin scale}

Figure 6 presents trends in annual (water year) evapotranspiration and sublimation for various HRUs. Evapotranspiration (ET) refers to the actual wetted surface and canopy intercepted rain evaporation and plant transpiration as calculated by Penman-Monteith (P-M) and Priestley-Taylor ( $\mathrm{P}-$ $\mathrm{T}$; wetlands and lakes) methods (Krogh et al., 2017), but restricted by not only stomatal conductance in $\mathrm{P}-\mathrm{M}$ but also by available storage of intercepted rainfall, ponded surface water and soil moisture content and the soil moisture withdrawal curve in CRHM. ET in $\triangle \mathrm{C}$ and $\triangle \mathrm{CV}$ has been significantly decreasing between 2 and $5 \mathrm{~mm} \mathrm{decade}^{-1}$ for some HRUs, whereas in $\Delta \mathrm{V}$ it has been increasing from HRU no. 3 (upper gully/drift). Evaporation from canopy rainfall inter-
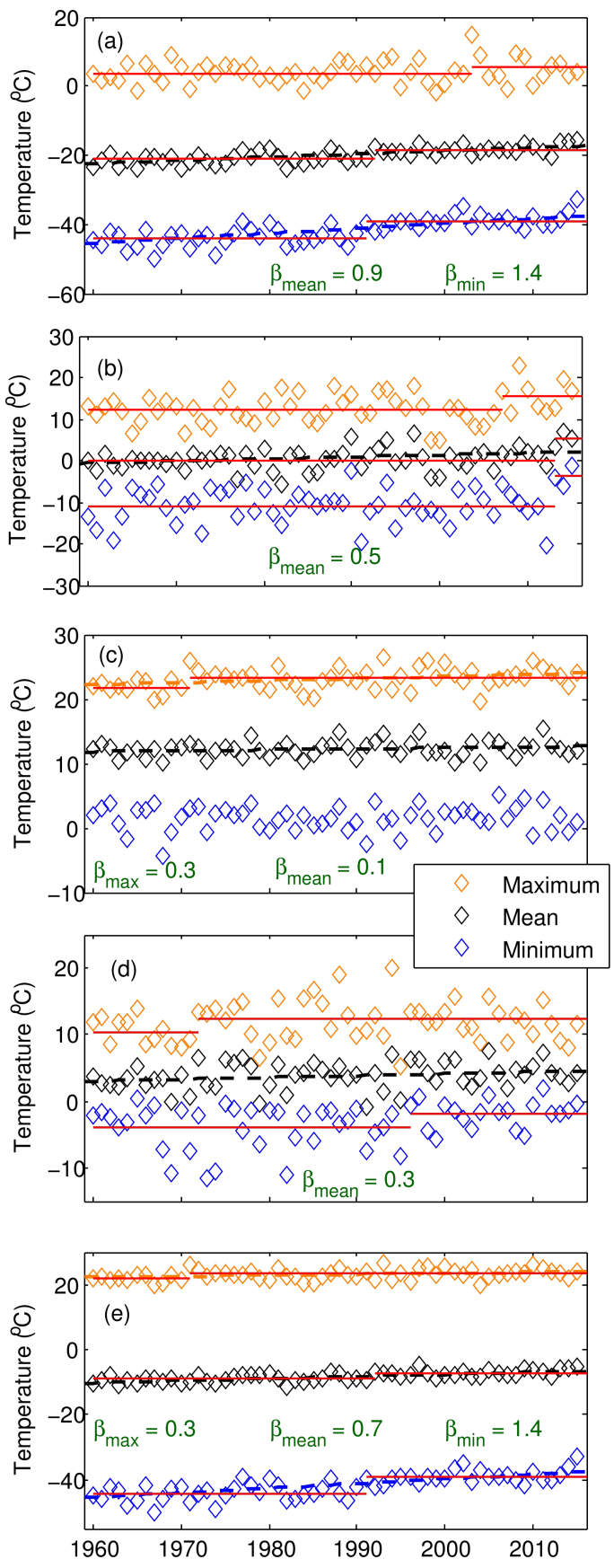

Figure 5. Observed seasonal and annual maximum, mean and minimum temperature for each water year (October-September) calculated from mean daily temperature, between 1960 and 2015 . (a) Winter (October-April), (b) spring (May), (c) summer (JuneAugust), (d) fall (September) and (e) annual. The dashed line is the linear regression using Sen (1968). The slope $(\beta)$ in ${ }^{\circ} \mathrm{Cdecade}^{-1}$ for statistically significant trends at the $p \leq 0.05$ significance threshold is shown. The solid red line shows the annual change point. 
Table 2. Slope for statistically significant weather trends at the $p \leq 0.05$ significance threshold using the Mann-Kendall test.

\begin{tabular}{lrcrcc}
\hline Period & $\begin{array}{r}\text { Short-wave } \\
\text { irradiance } \\
\left(\mathrm{W} \mathrm{m}^{-2} \mathrm{decade}^{-1}\right)\end{array}$ & $\begin{array}{c}\text { Long-wave } \\
\text { irradiance } \\
\left(\mathrm{W} \mathrm{m}^{-2} \mathrm{decade}^{-1}\right)\end{array}$ & $\begin{array}{r}\text { All-wave } \\
\text { irradiance } \\
\left(\mathrm{W} \mathrm{m}^{-2} \text { decade }^{-1}\right)\end{array}$ & $\begin{array}{c}\text { Wind speed } \\
\left(\mathrm{m} \mathrm{s}^{-1} \text { decade }^{-1}\right)\end{array}$ & $\begin{array}{c}\text { Relative } \\
\text { humidity } \\
\left(\% \text { decade }^{-1}\right)\end{array}$ \\
\hline Winter & 0.8 & 2.8 & 3.9 & - & 0.6 \\
Spring & -4.3 & 2.4 & - & - & - \\
Summer & -6 & 3.3 & -2.9 & -0.1 & 1.4 \\
Fall & - & 3.7 & 2.4 & - & 1.2 \\
\hline Annual & -1.4 & 2.9 & 1.5 & - & 0.8 \\
\hline
\end{tabular}
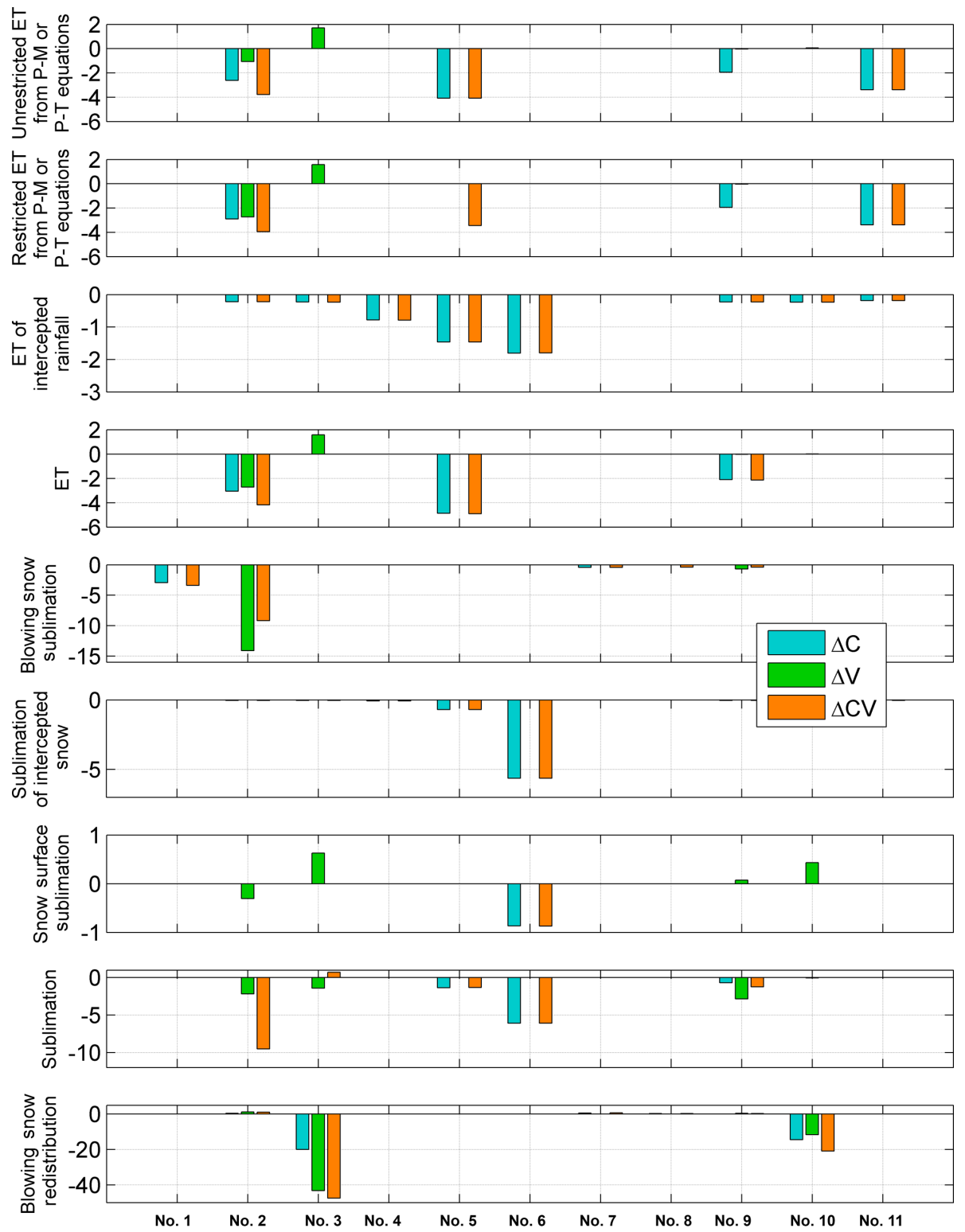

Figure 6. Units in mm decade ${ }^{-1}$. Scenario comparison of significant trends $(p \leq 0.05)$ for selected mass fluxes at an HRU-scale. The $x$ axis is as follows: upper tundra (no. 1), upper sparse shrubs (no. 2), upper gully/drift (no. 3), close shrubs (no. 4), taiga forest (no. 5), forest (no. 6), lower tundra (no. 7), open water (no. 8), lower sparse shrubs (no. 9), lower gully/drift (no. 10) and wetland (no. 11). 

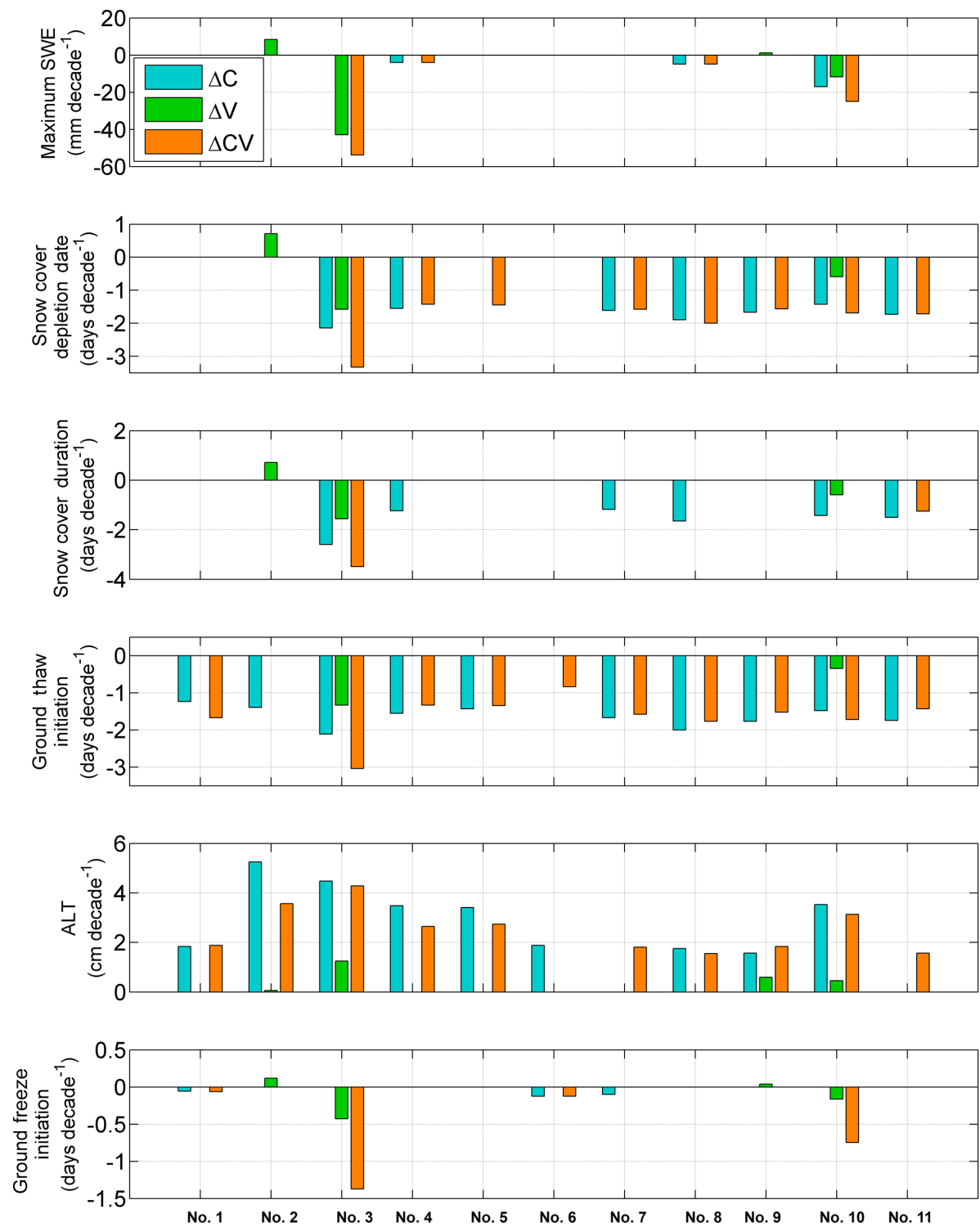

Figure 7. Comparison of significant trends $(p \leq 0.05)$ for snow and ground freeze/thaw-related variables at HRU scale for the three scenarios. Note that trends for snow cover depletion date, snow cover duration and ground thaw initiation are in dates, and for maximum SWE, ALT and snow ablation are shown in rates. The $x$ axis is as follows: upper tundra (no. 1), upper sparse shrubs (no. 2), upper gully/drift (no. 3), close shrubs (no. 4), taiga forest (no. 5), forest (no. 6), lower tundra (no. 7), open water (no. 8), lower sparse shrubs (no. 9), lower gully/drift (no. 10) and wetland (no. 11). ALT: active layer thickness. SWE: snow water equivalent.

ception has been decreasing by up to $2 \mathrm{~mm}^{\text {decade }}{ }^{-1}$ in $\Delta \mathrm{C}$ and $\triangle \mathrm{CV}$ for most HRUs, but has no trend in $\Delta \mathrm{V}$ where only vegetation increases. Soil-moisture-restricted and soilmoisture-unrestricted ET from $\mathrm{P}-\mathrm{M}$ and $\mathrm{P}-\mathrm{T}$ equations has virtually the same trends, except from taiga forest (HRU no. 5), suggesting that soil moisture content has had little effect on ET. Blowing snow sublimation has a decreasing trend in the upper and lower shrub HRUs for $\Delta \mathrm{V}$ and $\triangle \mathrm{CV}$ where vegetation increases, with the largest trend in the upper basin $\left(\sim-14 \mathrm{~mm} \mathrm{decade}^{-1}\right)$. Decreasing blowing snow sublimation by $3 \mathrm{~mm}$ decade $^{-1}$ was found in the upper tundra HRU for $\Delta \mathrm{C}$ and $\Delta \mathrm{CV}$. Sublimation from canopyintercepted snow has a decreasing trend for all of the vegetated HRUs in $\Delta \mathrm{C}$ and $\Delta \mathrm{CV}$, with the largest trend in the forest HRU (roughly $6 \mathrm{~mm}_{\text {decade }}{ }^{-1}$ ). Sublimation at the snow surface has a decreasing trend in the forest (HRU no. 6) in

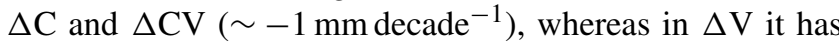
an increasing trend in the upper and lower gully/drift (HRU no. 3 and no. 10) and a decreasing trend in the upper shrub HRU. Annual sublimation, defined as the sum of the previous three sublimation terms, has a decreasing trend in $\Delta \mathrm{V}$ for the upper and lower shrubs and upper Gully/drift (about 
Table 3. Mean change point analysis of the atmospheric forcing variables.

\begin{tabular}{|c|c|c|}
\hline Atmospheric variable & $\begin{array}{l}\text { Mean } \\
\text { annual } \\
\text { change }\end{array}$ & Year \\
\hline Precipitation (mm) & 369 to 321 & 1972 \\
\hline Air temperature $\left({ }^{\circ} \mathrm{C}\right)$ & -9.1 to -7.1 & 1992 \\
\hline Short-wave irradiance $\left(\mathrm{W} \mathrm{m}^{-2}\right)$ & 112 to 104 & 1969 \\
\hline Long-wave irradiance $\left(\mathrm{W} \mathrm{m}^{-2}\right)$ & 230 to 242 & 1969 \\
\hline All-wave irradiance $\left(\mathrm{W} \mathrm{m}^{-2}\right)$ & 344 to 348 & 1997 \\
\hline Wind speed $\left(\mathrm{m} \mathrm{s}^{-1}\right)$ & $\mathrm{n} / \mathrm{a}$ & $\mathrm{n} / \mathrm{a}$ \\
\hline Relative humidity (\%) & 69 to 75 & 2013 \\
\hline
\end{tabular}

n/a means not applicable.

2 to $3 \mathrm{~mm} \mathrm{decade}^{-1}$, respectively). In $\Delta \mathrm{C}$ and $\Delta \mathrm{CV}$ it has a decreasing trend in the forested HRUs and lower shrub HRU, driven by the decreasing sublimation from canopy interception, which is the dominant sublimation term over the basin (Krogh et al., 2017). Blowing snow redistribution, defined as the divergence between incoming and outgoing blowing snow transport, decreased in the upper and lower gully/drift HRU for all scenarios, between -20 and $-45 \mathrm{~mm}$ decade $^{-1}$ in the upper basin and -10 and $-20 \mathrm{~mm} \mathrm{decade}^{-1}$ in the lower basin.

Figure 7 present a series of trends related to snow cover and ground freeze/thaw. Maximum SWE for $\Delta \mathrm{C}$ decreased in some HRUs, with the largest trend in the lower sparse shrub HRU $\left(-17 \mathrm{~mm} \mathrm{decade}^{-1}\right)$, whereas for $\Delta \mathrm{CV}$ the largest decreasing trend was found in the upper gully/drift HRU ( $-54 \mathrm{~mm} \mathrm{decade}^{-1}$ ). Maximum SWE for $\Delta \mathrm{V}$ showed increasing and decreasing trends in the sparse shrub and gully/drift HRUs, respectively, with the largest changes found in the upper basin. Note that increasing vegetation cover and density hampered blowing snow transport from sparse shrub towards gully/drift HRUs (Fig. 6). The snow cover depletion date for $\Delta \mathrm{C}$ and $\Delta \mathrm{CV}$ advanced in almost all HRUs, around -1 and -3 days decade ${ }^{-1}$, whereas for $\Delta \mathrm{V}$, both advance and retreat were found in the upper sparse shrub and gully/drift HRUs, respectively. Snow cover duration for $\Delta \mathrm{C}$ and $\Delta \mathrm{CV}$ declined for some HRUs (around -1 and -3 days decade $^{-1}$ ), whereas for $\Delta \mathrm{V}$, both extension and decline was found in the upper sparse shrub and gully/drift HRUs (roughly 1 and -1 days decade ${ }^{-1}$ ). Ground thaw initiation had similar changes as the snow cover depletion timing, which is expected as ground thaw typically starts once the ground is snow-free and temperatures are above $0{ }^{\circ} \mathrm{C}$. Active layer thickness (ALT) for $\Delta \mathrm{C}$ and $\Delta \mathrm{CV}$ deepened throughout the basin at a rate of between 2 and $5 \mathrm{~cm} \mathrm{decade}^{-1}$, whereas for $\Delta \mathrm{V}$ it deepened in the sparse shrub and gully/drift HRUs $\left(<2 \mathrm{~cm} \mathrm{decade}^{-1}\right)$. Snow ablation rate, here defined as the ratio between the maximum SWE and the number of days between maximum SWE and
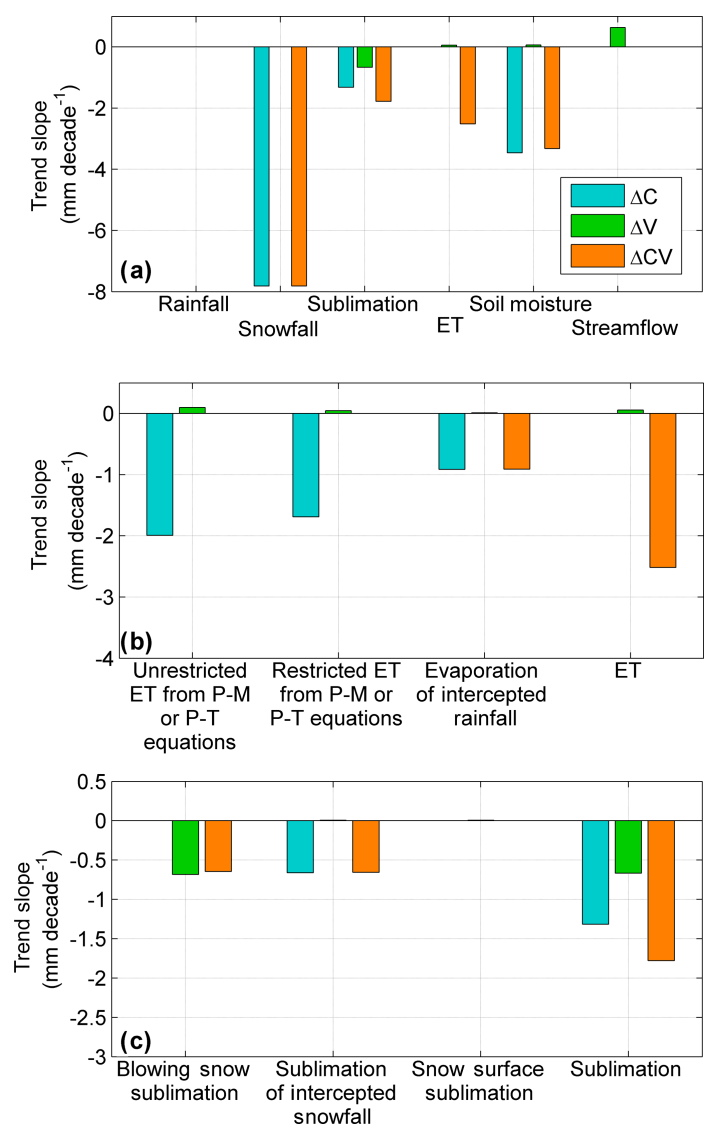

Figure 8. Comparison of basin-scale annual mass fluxes trends ( $p \leq 0.05$ ) over the water years from 1960 to 2015 , for the three scenarios. (a) Main mass fluxes. (b) Evapotranspiration components. (c) Sublimation components.

the depletion of snow cover, decreased for $\Delta \mathrm{C}$ and $\Delta \mathrm{CV}$ in some HRUs by between -0.1 and $-1.5 \mathrm{~mm} \mathrm{day}^{-1}$ decade $^{-1}$, whereas for $\Delta \mathrm{V}$ it increased in the sparse shrub and decreased in the gully/drift HRUs.

\subsubsection{Basin scale}

The primary annual mass flux trends from the three modelling scenarios are presented in Fig. 8 at the basin scale. No trend was found for annual rainfall depths; however, a decreasing trend of $-7.8 \mathrm{~mm} \mathrm{decade}{ }^{-1}$ was found for snowfall depths in $\Delta \mathrm{C}$ and $\Delta \mathrm{CV}$. The rainfall ratio (rainfall divided by total precipitation) exhibited no trend. Annual sublimation losses decreased by $-1.3,-0.7$ and $-1.8 \mathrm{~mm} \mathrm{decade}^{-1}$ in scenarios $\Delta \mathrm{C}, \Delta \mathrm{V}$ and $\Delta \mathrm{CV}$, respectively. The sublimation trend in $\Delta \mathrm{C}$ was driven by decreasing sublimation from canopy interception, likely due to decreasing snowfall. Decreasing sublimation in the $\Delta \mathrm{V}$ scenario was driven by decreasing blowing snow sublimation caused by expanding and densifying tundra shrubs, whereas for the $\triangle \mathrm{CV}$ scenario, both drove sublimation trends. Annual ET losses decreased by $-2.5 \mathrm{~mm} \mathrm{decade}^{-1}$ in $\Delta \mathrm{CV}$, in contrast to the trend to 
increase by $0.06 \mathrm{~mm}_{\text {decade }}{ }^{-1}$ for $\Delta \mathrm{V}$, driven by positive trends in all ET components. ET in $\Delta \mathrm{C}$ showed no trend. Decreasing ET in $\triangle \mathrm{CV}$ was driven by a decreasing trend in evaporation of rain intercepted in the canopy. To investigate the potential impact of changes in stomata resistance on evapotranspiration, trends in mean annual stomata resistance were also calculated. For both scenarios with changing climate $(\Delta \mathrm{C}$ and $\Delta \mathrm{CV})$, no trend was found; however, for the changing vegetation-only scenario $(\Delta \mathrm{V})$ a positive trend of $1.6 \mathrm{~s} \mathrm{~m}^{-1}$ decade $^{-1}$ was found, which agrees with the small increase in ET found for this scenario. Annual streamflow shows an increasing trend of $0.6 \mathrm{~mm}$ decade $^{-1}$ only for $\Delta \mathrm{V}$, likely due to the increasing snow accumulation at some HRUs (Fig. 6) as a result of reduced blowing snow transport.

Table 4 presents the change point analysis for selected annual mass fluxes at the basin scale for the three scenarios. Rainfall shows an increase from 131 to $196 \mathrm{~mm}$ in 2013, whereas snowfall decreases from 211 to $169 \mathrm{~mm}$ in 1997. Similarly to the trend analysis, sublimation shows a decrease in all the modelling scenarios, from 39 to $28 \mathrm{~mm}$, 37 to $35 \mathrm{~mm}$ and 42 to $36 \mathrm{~mm}$, for $\Delta \mathrm{C}, \Delta \mathrm{V}$ and $\Delta \mathrm{CV}$, respectively. ET, which showed no significant trend for $\Delta \mathrm{C}$, presents a decreasing change point from 160 to $144 \mathrm{~mm}$ for $\Delta \mathrm{C}$, driven by the drier conditions. ET for $\Delta \mathrm{V}$ shows no change point, despite the small significant trend in ET $\left(0.06 \mathrm{~mm} \mathrm{decade}^{-1}\right)$. For the combined scenario $(\Delta \mathrm{CV})$ ET shows a decrease change point in 1977 from 160 to $144 \mathrm{~mm}$, driven by drier conditions and the decrease in radiative energy for ET (all-wave irradiance). Streamflow for $\Delta \mathrm{C}$ has a decreasing change point from 180 to $140 \mathrm{~mm}$ in 1973 , despite the lack of significant trend (Fig. 8). For $\Delta \mathrm{V}$, streamflow has a small increase from 133 to $135 \mathrm{~mm}$ in 1992, which somewhat counteracts the effect of changing climate (180 to $140 \mathrm{~mm}$ ), resulting in a smaller change from 178 to $140 \mathrm{~mm}$ in 1973 for $\Delta \mathrm{CV}$.

\subsection{Streamflow regime change}

The $\Delta \mathrm{CV}$ scenario most comprehensively represents historical change in climate and vegetation in the Havikpak Creek basin; therefore, it was used to estimate and diagnose changes in streamflow. Figure 9 presents annual time series of variables associated with annual streamflow and peak streamflow for the water years between 1960 and 2015. These time series are annual streamflow volume (Fig. 9a), annual peak daily streamflow discharge (Fig. 9b), date (day of the year, DOY) of peak discharge (Fig. 9c), the DOY of the centre of mass (50\% of volume passed) of streamflow discharge (Fig. 9d) and daily streamflow discharge associated with different exceedance probabilities: 5, 25, 50,75 and $95 \%$, using a Weibull distribution function (Fig. 9e). The Weibull distribution was used as it successfully represents daily streamflow probability distribution at HPC (not shown). The DOY of peak daily annual streamflow and the DOY
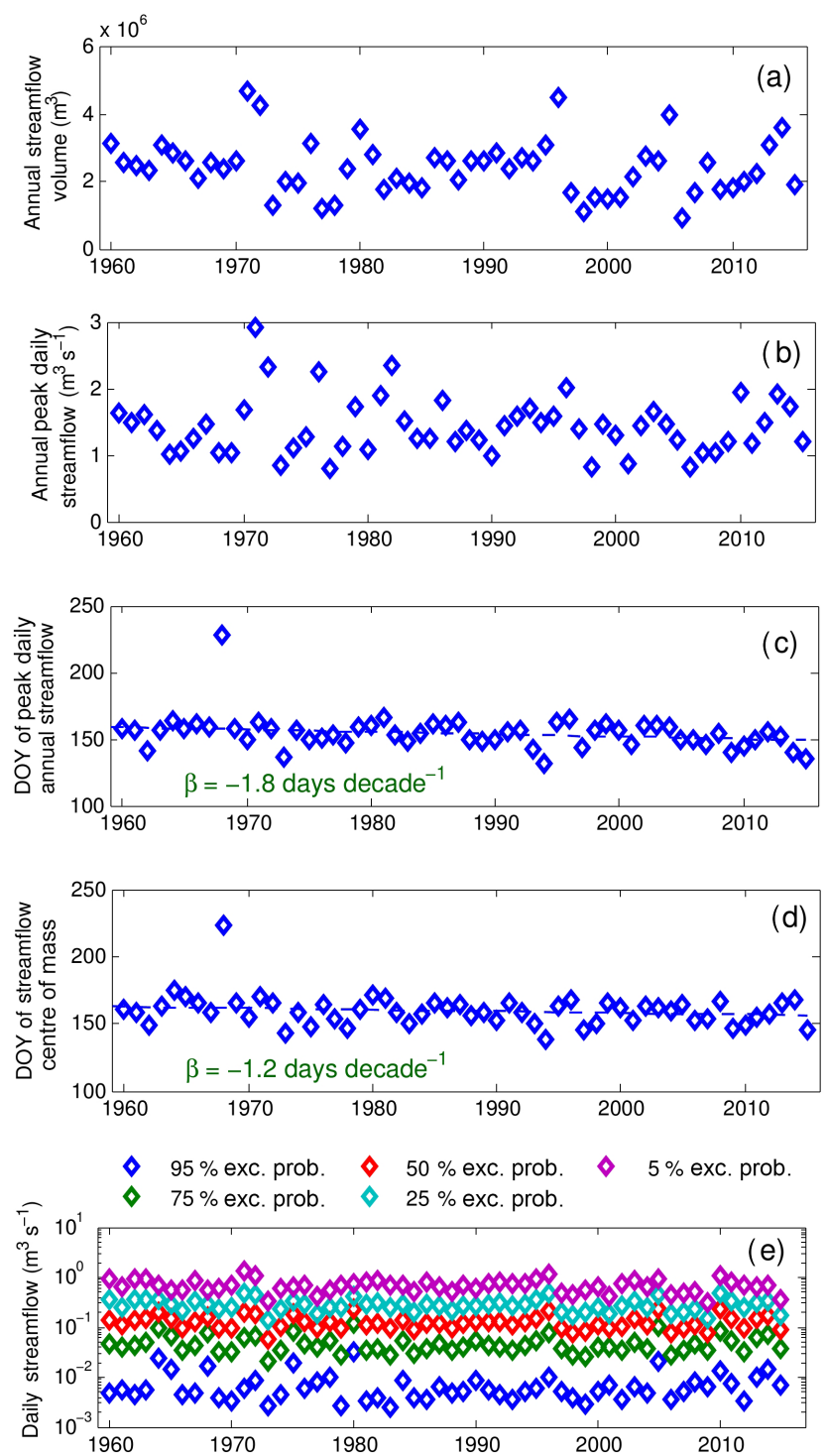

Figure 9. (a) Annual streamflow volume. (b) Annual peak daily streamflow. (c) Day of the year (DOY) of peak daily streamflow. (d) DOY of streamflow volume discharge centre of mass. (e) Streamflow discharge associated with various exceedance probabilities. The $x$ axis of all subplots is the water year starting in October.

of the streamflow's centre of mass decreased by -1.8 and 1.2 days decade $^{-1}$, respectively. This finding is consistent with the earlier snow depletion date shown in Fig. 7. The abnormally high value for the DOY peak daily annual streamflow and of the streamflow's centre of mass (Fig. 9c and d; $\mathrm{DOY}=226$, mid-August) for the water year 1968 is associated with a water year with abnormally high rainfallrunoff compared to snowmelt runoff. No trends were found in monthly streamflow volumes for each month between May and October (not shown), except for September, which decreased at about $-47.1 \mathrm{~m}^{3} \mathrm{decade}^{-1}$. 
Table 4. Change point analysis for selected annual basin-scale mass fluxes for the three modelling scenarios.

\begin{tabular}{|c|c|c|c|c|c|c|}
\hline \multirow[t]{2}{*}{ Mass fluxes } & \multicolumn{2}{|c|}{$\Delta \mathrm{C}: \Delta$ climate-only } & \multicolumn{2}{|c|}{$\Delta \mathrm{V}: \Delta$ vegetation-only } & \multicolumn{2}{|c|}{$\Delta \mathrm{CV}: \Delta$ climate and vegetation } \\
\hline & $\begin{array}{l}\text { Mean } \\
\text { change } \\
(\mathrm{mm})\end{array}$ & Year & $\begin{array}{l}\text { Mean } \\
\text { change } \\
(\mathrm{mm})\end{array}$ & Year & $\begin{array}{l}\text { Mean } \\
\text { change } \\
(\mathrm{mm})\end{array}$ & Year \\
\hline Rainfall & 131 to 196 & 2013 & $\mathrm{n} / \mathrm{a}$ & $\mathrm{n} / \mathrm{a}$ & 131 to 196 & 2013 \\
\hline Snowfall & 211 to 169 & 1997 & $\mathrm{n} / \mathrm{a}$ & $\mathrm{n} / \mathrm{a}$ & 211 to 169 & 1997 \\
\hline Sublimation & 39 to 28 & 2013 & 37 to 35 & 1988 & 42 to 36 & 1980 \\
\hline ET & 160 to 144 & 1977 & $\mathrm{n} / \mathrm{a}$ & $\mathrm{n} / \mathrm{a}$ & 160 to 144 & 1977 \\
\hline Soil moisture & 80 to 48 & 1968 & $\mathrm{n} / \mathrm{a}$ & $\mathrm{n} / \mathrm{a}$ & 82 to 49 & 1968 \\
\hline Streamflow & 180 to 140 & 1973 & 133 to 135 & 1992 & 178 to 140 & 1973 \\
\hline
\end{tabular}

n/a means not applicable.

Figure 10 presents the mean daily streamflow discharge for observed streamflow (1995-2015) and the three modelling scenarios over the period 1960-2016. The $\Delta \mathrm{C}$ and $\Delta \mathrm{CV}$ scenarios show very similar mean hydrographs, with streamflow discharge starting in mid-April reaching the peak discharge at $0.7 \mathrm{~m}^{3} \mathrm{~s}^{-1}$ on 8 June and ending by midNovember. The $\Delta \mathrm{V}$ scenario presents a very different mean discharge response, which is not surprising as meteorological drivers largely control the mean conditions and these were kept constant in this scenario. Under this scenario $(\Delta \mathrm{V})$, streamflow starts in mid-May reaching the peak discharge at $1.7 \mathrm{~m}^{3} \mathrm{~s}^{-1}$ on $22 \mathrm{May}$, and it ends in mid-August, having a much shorter discharge season. The current mean hydrological regime, discussed in detail by Krogh et al. (2017), shows an earlier peak flow compared with the long-term $\Delta \mathrm{C}$ or $\Delta \mathrm{CV}$ scenarios, which is consistent with the reduction in the date of peakflow presented in Fig. 9c. Also, larger latefall streamflow discharge is present under current conditions.

\subsection{Teleconnections}

Table 5 lists Pearson correlations coefficients between annual basin-scale mass fluxes and five climatic indices. Statistically significant correlation coefficients with $p$ values $\leq 0.05$ are in bold. Significant correlations were found between some mass fluxes and the North Pacific Index (NPI), Southern Oscillation Index (SOI) and Pacific Decadal Oscillation (PDO); however, even significant Pearson coefficients were relatively low $(\leq 0.4)$, suggesting that large-scale climatic oscillations do not have an important effect on Havikpak Creek basin hydrology. The same analysis on a seasonal scale provided similarly low correlation coefficients (not shown).

\section{Discussion}

\subsection{Changing climate}

The increasing air temperature trends at Inuvik found in this study (Fig. 5) qualitatively agree with those trends

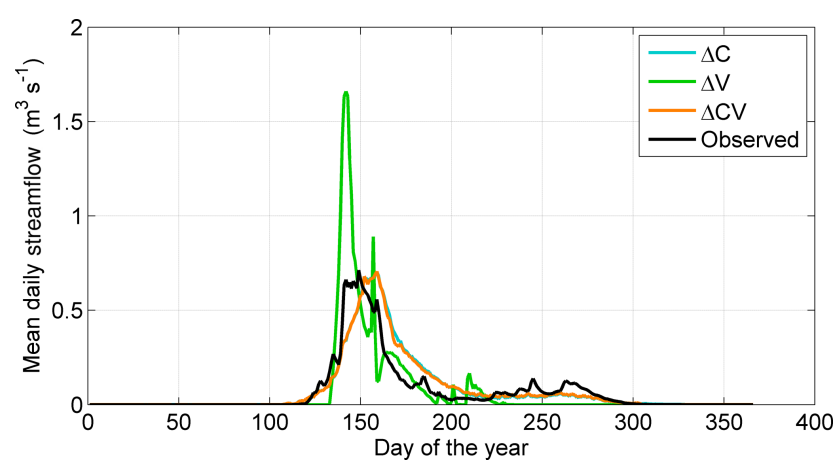

Figure 10. Mean annual hydrograph for the observed streamflow (1995-2015), and the three modelling scenarios (1960-2016): changing climate-only $(\Delta \mathrm{C})$, changing vegetation-only $(\Delta \mathrm{V})$ and changing climate and vegetation $(\Delta \mathrm{CV})$. Note the overlap between the $\Delta \mathrm{C}$ and $\Delta \mathrm{CV}$ scenarios.

found by other studies using gridded data products (DeBeer et al., 2016; Vincent et al., 2015). Inuvik winters have warmed to the greatest degree; minimum and mean air temperature have increased by 8.0 and $5.2{ }^{\circ} \mathrm{C}$, respectively, over 1960-2016. No temporal trend in precipitation was found at Inuvik (Fig. 4), except for a decrease in the spring $\left(-2.7 \mathrm{~mm} \mathrm{decade}^{-1}\right.$; Fig. 4); however, the change point analysis showed an important decrease in the year 1972 from 369 to $321 \mathrm{~mm} \mathrm{yr}^{-1}$ for the mean annual precipitation (Table 3). Vincent et al. (2015) investigated long-term trends in precipitation records over Canada for the period between 1948 and 2012 using the gridded and spatially interpolated CANGRD dataset (Rapaic et al., 2015). For the region around Havikpak Creek Vincent et al. (2015) showed significant spatial variability with a small increase of less than $10 \%$ in annual precipitation. The CANGRD dataset is a spatially interpolated $50 \mathrm{~km}$ product that is based on the AHCCD dataset and has shown problems when compared against weather station data, particularly north of $60^{\circ} \mathrm{N}$ (Milewska and Hogg, 2001). Different trends found in this study and Vincent et al. (2015) can be explained by interpolation errors 
Table 5. Pearson correlation coefficient between basin-scale mass fluxes and climatic indexes, using water year values (October-September). Correlation coefficients with $p$ values $\leq 0.05$ are in bold.

\begin{tabular}{lrrrrr}
\hline Climatic index & AO & NAO & NPI & SOI & PDO \\
\hline Rainfall & 0.134 & 0.002 & 0.207 & -0.007 & -0.110 \\
Snowfall & -0.013 & 0.151 & 0.116 & -0.168 & 0.022 \\
Precipitation & 0.075 & 0.114 & 0.219 & -0.130 & -0.054 \\
Sublimation & -0.021 & 0.125 & 0.256 & 0.185 & $\mathbf{- 0 . 3 4 0}$ \\
Blowing snow sublimation & 0.044 & 0.020 & $\mathbf{0 . 3 3 6}$ & 0.200 & $\mathbf{- 0 . 3 9 7}$ \\
Snowpack sublimation & -0.049 & 0.077 & 0.108 & 0.203 & -0.249 \\
Sublimation of intercepted snowfall & -0.014 & 0.172 & 0.143 & -0.071 & -0.058 \\
Restricted ET from P-M or P-T equations & 0.161 & -0.200 & 0.253 & $\mathbf{0 . 2 6 8}$ & $\mathbf{- 0 . 3 3 2}$ \\
Evaporation from canopy interception & -0.034 & 0.125 & -0.017 & -0.078 & 0.061 \\
ET & 0.156 & -0.183 & 0.250 & 0.256 & $\mathbf{- 0 . 3 2 3}$ \\
Soil moisture & -0.010 & -0.158 & 0.191 & -0.065 & -0.073 \\
Streamflow & -0.002 & 0.062 & 0.083 & -0.262 & 0.141 \\
\hline
\end{tabular}

in the CANGRD dataset and the different period of analysis. This suggests that careful assessment of regional climate products needs to be performed when looking at individual sites, particularly in the Arctic where there are few stations.

As presented in Sect. 3.2, the precipitation time series was produced using mostly the AHCCD dataset and corrected records from automated weather stations (AWSs) for wind undercatch, producing a discontinuity in the time series in the mid-1990s. Although uncertainty exists in the precipitation records, there is a relatively high confidence in the accuracy of precipitation, supported by the typically low wind speed limiting wind undercatch losses, the meticulous quality control and corrections used in the AHCCD dataset (Mekis and Vincent, 2011), the well-established wind undercatch correction used for the AWS snow gauge and the snow surveys from small clearing with minimal snow distribution and sublimation that allows a good estimation of seasonal snowfall. Comparing this precipitation dataset with another nearby station is challenging, as there is no station with similar longterm records close to Inuvik. Nevertheless, the impacts of such uncertainty on the presented results are expected to be small and should not change the core discussions and conclusions of this study.

Mean annual short-wave irradiance from combined ERA40 and ERA-I decreased by $-1.4 \mathrm{~W} \mathrm{~m}^{-2}$ decade $^{-1}$ (Table 2) or $-7.4 \%$ over $1960-2016$ with respect to 1960 . Other studies have also found that measured solar irradiance in the Arctic has decreased. For example, Weston et al. (2007) found a decreasing trend in solar irradiance at two Canadian Arctic sites: Alert and Resolute Bay, Nunavut Territory, for the period 1964-2002 and 1957-2003, respectively. They argued that decreases in short-wave irradiance are driven by changes in atmospheric composition, such as aerosols and greenhouse gases, producing a decreasing in the calculated daily Clearness Index. However, the ERA-I irradiance model calculation (Saunders et al., 1999) does not include the effect of aerosol scattering, but it does include the effect of green- house gasses, such as water vapour and carbon monoxide. Mean annual long-wave irradiance shows an increasing trend of $2.9 \mathrm{~W} \mathrm{~m}^{-2}$ decade $^{-1}$ (Table 2) or $7.3 \%$ over 1960-2016 with respect to 1960 . This result agrees with global observations, showing an increase in long-wave radiation (Ohmura, 2009), particularly over the Canadian Arctic, for which observed net long-wave is also increasing (Weston et al., 2007), and is consistent with an increase in cloud cover and/or water vapour in the atmosphere with resulting increasing atmospheric emissivity and/or increasing air temperatures. The annual modelled all-wave irradiance is increasing by $2.6 \%$, but with seasonal variations. Winter all-wave irradiance has been increasing by $10 \%$, providing more energy to snowmelt and sublimation, whereas summer all-wave irradiance has been decreasing by $3 \%$, which decreases the energy for ET and ground thaw.

\subsection{Changes to the hydrological cycle}

The precipitation phase shifted from snowfall to rainfall in the scenarios including climate change $(\Delta \mathrm{C}$ and $\Delta \mathrm{CV}$; Fig. 8) by $22.7 \%$ from 1960 to 2016; this was driven by the increase in mean annual air temperature of $3.7^{\circ} \mathrm{C}$ (Table 1). Snow cover duration decreased for $\Delta \mathrm{C}$ (some HRUs; Fig. 7), whereas for $\Delta \mathrm{V}$ both decreased and increased over the HRUs; however, the $\triangle \mathrm{CV}$ resulted in a shortened snow season (most HRUs). This shortening was mostly driven by changing climate with reduced snowfall and snow redistribution to drifts by wind. Similarly to the snow season duration, the snow cover depletion date for $\triangle \mathrm{CV}$ decreased between 8 and 17 days over 1960-2016 (Fig. 7), with the greatest decrease in the upper gully/drift HRU, due to decreasing blowing snow redistribution and hence peak SWE. As peak streamflow in HPC is dominated by snowmelt events, these changes are consistent with the 10-day advance in peak streamflow date. Peak SWE decreased between 12 and $33 \%$ in the $\Delta \mathrm{C}$, whereas for $\Delta \mathrm{V}$ it increased in the sparse shrub 
HRUs by 3 to $30 \%$ and decreased in the gully/drift HRUs by 22 to $40 \%$. The $\Delta \mathrm{CV}$ scenario resulted in diminishing peak SWE by 12 to $50 \%$, due to the combination of decreasing snowfall and blowing snow redistribution from sparse shrubs to gully/drift HRUs. Snow ablation rates for $\Delta \mathrm{C}$ decreased by 0.3 to $1.1 \%$ over $1960-2016$, whereas for $\Delta \mathrm{V}$ they decreased in the sparse shrub HRUs by 0.3 to $0.4 \%$ and increased by 0.31 to $0.4 \%$ in the gully/drift HRUs. Changes in snow ablation rates due to a warmer climate have been investigated in other cold regions. Rasouli et al. (2014) and Pomeroy et al. (2015) modelled snow hydrology in mountain basins in Yukon and Alberta, Canada, respectively, and attributed the lower snow ablation rates under climate change to an earlier snowmelt season, occurring when lower solar radiation inputs are available. Using snow accumulation records in the western USA, Musselman et al. (2017) reached a similar conclusion. López-Moreno et al. (2012) also found a reduction in ablation rates in the Spanish Pyrenees under a scenario of warmer temperatures. However, here some snow ablation rates increased for $\Delta \mathrm{V}$, suggesting climatic factors are not the only control in ablation rates, but that vegetation dynamics can compensate or even reverse trends in ablation rates due to changing climate.

Sublimation decreased in $\Delta \mathrm{C}$ by $23 \%$, due to a decrease in sublimation of intercepted snow by $19 \%$. Factors decreasing sublimation of intercepted snow are warmer temperatures, causing accelerated snow unloading from the canopy, and decreasing snowfall. Sublimation for $\Delta \mathrm{V}$ decreased by $10 \%$, due to blowing snow sublimation dropping by $44 \%$, mostly in the upper basin. Decreasing blowing snow in this scenario is driven by shrub densification, increasing the aerodynamic roughness height and wind speeds required to initiate blowing snow transport. Shrub densification intensified the effect of changing climate on sublimation, decreasing sublimation by $29 \%$ over the study period. ET did not show a significant trend in the changing climate-only scenario; however, the ET of intercepted rainfall and soil moisture-restricted ET from the $\mathrm{P}-\mathrm{M}$ or $\mathrm{P}-\mathrm{T}$ equations decreased by 51 and $6 \%$, respectively. This is explained by the different inter-annual variability of the two ET terms hampering the individual trends; nevertheless, the change point analysis of mean annual ET shows a decrease of $16 \mathrm{~mm} \mathrm{yr}^{-1}$ in 1977 (9.5\% with respect to 1960 for $\Delta \mathrm{C}$ and $\Delta \mathrm{CV}$ ), consistently with the simulated trends of each ET component. ET for $\Delta \mathrm{V}$ increased by a marginal $0.2 \%$, due to the $1.5 \%$ increase in soil moisture content and $0.8 \%$ increase in ET of intercepted rainfall due to shrub expansion. The combined effect of changing climate and vegetation decreased ET by $8.5 \%$, driven largely by changing climate. Decreasing summer all-wave irradiance $(3 \%)$ and soil moisture content (19\%) were driving decreasing ET in the scenario with combined climate and vegetation changes.

Active layer thickness (ALT) for $\Delta \mathrm{C}$ increased by 11 to $28 \mathrm{~cm}$ over 1960-2016 for most HRUs, caused by the earlier snow depletion date ( 8 to 11 days) and ground thaw initiation (6 to 11 days), and warmer ground-surface temperatures due to warmer air temperatures. ALT increased up to $7 \mathrm{~cm}$ for $\Delta \mathrm{V}$ in some HRUs, driven by the earlier snow cover depletion date ( 3 to 8 days) and ground thaw initiation ( 2 to 6 days). The effect of changing vegetation dampened the deepening in ALT found in the $\Delta \mathrm{C}$ scenario for most HRUs; nevertheless, in the $\triangle \mathrm{CV}$ scenario, ALT increased by 11 to $22 \mathrm{~cm}$.

Annual streamflow volume from HPC has dropped by $38 \mathrm{~mm}(21 \%)$ whilst annual precipitation has dropped by $48 \mathrm{~mm}(13 \%)$ since 1960 . We argue that the $10 \mathrm{~mm}(21 \%)$ difference between the decrease in precipitation and streamflow discharge from HPC suggests a small degree of hydrological resiliency, here defined as the capacity of a basin to actively counteract the impact of changes in weather on streamflow discharge, which is explained by the declining ET and sublimation. This result emphasizes the need for a full physically based representation of the hydrological cycle in models so that the processes driving this resiliency can be used to diagnose its function.

\subsection{Havikpak Creek basin changes versus other Arctic studies}

The $\triangle \mathrm{CV}$ scenario best represents historical change in Havikpak Creek basin; therefore, it is used to compare with other Arctic studies. Snow cover depletion dates in HPC accelerated between 1.5 and 3.2 days decade $^{-1}$ (Fig. 7), which are higher than the average trend presented by Liston and Hiemstra (2011) for the entire Arctic $\left(-1.28\right.$ days decade $\left.{ }^{-1}\right)$, but smaller than their largest trend in the Arctic ( -9.89 days decade $\left.{ }^{-1}\right)$. The maximum ALT depth increased by 1.8 to $4.2 \mathrm{~cm} \mathrm{decade}^{-1}$ (Fig. 7), which is smaller than the average trend of $4.7 \mathrm{~cm}^{-1 e c a d e}{ }^{-1}$ modelled by Oelke et al. (2004) over the Mackenzie River basin. Differences in ALT change simulations can be due to (1) differences in the model's spatial representation (Oelke et al., 2004 used grids of $25 \mathrm{~km}$, with which small-scale features are not well represented); (2) differences in the ground freeze/thaw method algorithm (Oelke et al. used a one-dimensional heat conduction, i.e. lateral flow is neglected); and (3) the driving meteorology (Oelke et al. used the NCEP/NCAR reanalysis, which has shown some problems in representing Arctic climate) (Serreze et al., 1998; Serreze and Hurst, 2000). However, the average permafrost conditions of the Mackenzie River basin are thinner and warmer compared with those in HPC, and so average changes in ALT are expected to be larger for the Mackenzie River basin than for HPC.

Annual streamflow volume at HPC has dropped (Table 4); unfortunately there are no long-term studies of small streams that originate in the Arctic to compare this result with. There are studies showing increasing large river basin streamflow into the Arctic (McClelland et al., 2006; Overeem and Syvitski, 2010; Peterson et al., 2002; Rood et al., 2017; Yang et al., 2002). However, a significant portion of the runoff in these basins originates south of the Arctic Circle (e.g. the Mackenzie and the Lena River basins in Canada and Russia, respec- 
tively), and therefore these trends are not representative of changes in Arctic hydrology. Previous studies have argued that the increase in the streamflow of large rivers flowing into the Arctic is driven by increasing baseflow due to permafrost thaw and increasing precipitation. However, HPC annual precipitation and streamflow have both dropped and the earlier shifts in the hydrograph are inconsistent with such mechanism. Instead, baseflow during the end of the summer is minimal, streamflow has been decreasing during September and no winter flow has been observed. Only a few similarities can be found between results of studies of large river basins flowing to the Arctic and HPC, such as increasing ALT and accelerating snow-free dates; however, most processes, such as evapotranspiration and streamflow, depend on the localscale interaction between several physical processes, which are undergoing distinct changes that are not evident in rivers flowing into the Arctic. Therefore, the results of studies of these large river basins should not be confused with the results for an Arctic hydrology study.

This study considered changing climate and transient vegetation change separately to identify their individual effects; nevertheless, they are strongly coupled in the historical record. Warming temperatures are well correlated with shrub growth (Myers-Smith et al., 2011), which has a positive feedback to atmospheric heating by decreasing surface albedo, generating greater sensible heat flux to the atmosphere (Pomeroy et al., 2006), and a negative feedback by consuming more atmospheric $\mathrm{CO}_{2}$ (Myers-Smith et al., 2011). The modelling scenario experiments here revealed that most simulated trends in the water balance are attributable to changes in climate; however, the effect of transient vegetation, as expressed in shrub expansion and densification, was shown to further reduce blowing snow redistribution and sublimation, which intensified climate-changedriven trends produced by the reduced snow accumulation. This emphasizes the need to include transient vegetation changes in hydrological simulations, which are typically neglected in hydrological models. Reliable rates of change in vegetation species, height and density need to be available for this purpose; therefore, comprehensive studies investigating these changes in other transitioning environments are needed.

\section{Conclusion}

This study diagnosed changes in the hydrology of a small Arctic basin in the tundra-taiga transition using a spatially distributed and physically based hydrological model. It considered both transient climate and vegetation changes for the first time. There was no evidence for intensification of the hydrological cycle as instead, most processes slowed. In the changing climate-only scenario, statistically significant changes were found for diminishing snow accumulation, sublimation, blowing snow redistribution, snow cover dura- tion, snow ablation rate and evapotranspiration, deepening active layer thickness and earlier snow cover depletion and ground thaw initiation. These, along with warming temperatures, declining summer net radiation and declining precipitation, resulted in diminished annual streamflow volume of $38 \mathrm{~mm}$ over the 56 years. However the decline in streamflow did not match the larger decline in precipitation $(48 \mathrm{~mm})$, providing some evidence of resilience to climate change, as despite rising temperatures, both evapotranspiration and sublimation dropped with declining precipitation and this attenuated the streamflow volume decline. Transient vegetation change further decreased blowing snow sublimation by reducing blowing snow transport. The combination of changing climate and transient vegetation change resulted in annual streamflow volume dropping by $38 \mathrm{~mm}$ over 56 years - a change that is not substantially different from that due to climate change alone. These results suggest that historical changes in vegetation and a degree of hydrological resiliency have not compensated for the effects of climate change on the hydrological regime of Havikpak Creek. They provide the first estimates of long-term change for a drainage basin located completely within the Arctic Circle, and demonstrate the large, complex and recent hydrological changes that have occurred, which can be used as a reference to inform other studies of Arctic climate change impacts.

Data availability. Weather and streamflow discharge data used in this study are available upon request from the corresponding author.

Author contributions. SAK and JWP designed the study. JWP developed the CRHM modelling platform. SAK performed the simulations and the statistical analyses and prepared the manuscript with contributions from JWP to the manuscript structure, readability and analysis and discussion of the results.

Competing interests. The authors declare that they have no conflict of interest.

Special issue statement. This article is part of the special issue "Understanding and predicting Earth system and hydrological change in cold regions". It is not associated with a conference.

Acknowledgements. Financial support for this study was provided by CONYCIT under the BECAS CHILE scholarship program, Global Water Futures, Changing Cold Regions Network, NSERC Discovery Grants, Canada Research Chairs and Yukon Environment. The authors thank Tom Brown of the Centre for Hydrology for providing technical support with the CRHM platform. Comments from Joseph Shea, Paul Whitfield, Lucia Scaff and two anonymous reviewers are greatly appreciated. 
Edited by: Bettina Schaefli

Reviewed by: two anonymous referees

\section{References}

Boé, J., Terray, L., Habets, F., and Martin, E.: Statistical and dynamical downscaling of the Seine basin climate for hydro-meteorological studies, Int. J. Climatol., 27, 1643-1655, https://doi.org/10.1002/joc.1602, 2007.

Bond, W. J. and Keeley, J. E.: Fire as a global 'herbivore': the ecology and evolution of flammable ecosystems, Trends Ecol. Evol., 20, 387-394, https://doi.org/10.1016/j.tree.2005.04.025, 2005.

Bonsal, B. R., Prowse, T. D., Duguay, C. R., and Lacroix, M. P.: Impacts of large-scale teleconnections on freshwater-ice break/freeze-up dates over Canada, J. Hydrol., 330, 340-353, https://doi.org/10.1016/j.jhydrol.2006.03.022, 2006.

Brown, R., Derksen, C., and Wang, L.: A multi-data set analysis of variability and change in Arctic spring snow cover extent, 1967-2008, J. Geophys. Res., 115, D16111, https://doi.org/10.1029/2010JD013975, 2010.

Burn, D. H. and Hag Elnur, M. A.: Detection of hydrologic trends and variability, J. Hydrol., 255, 107-122, https://doi.org/10.1016/S0022-1694(01)00514-5, 2002.

Cederstrom, D. J., Johnston, P. M., and Subitzky, S.: Occurrence and development of ground water in permafrost regions, Washington, D.C., available at: https://pubs.usgs.gov/circ/1953/0275/ report.pdf (last access: 12 July 2018), 1953.

Chow, D. and Levermore, G. J.: New algorithm for generating hourly temperature values using daily maximum, minimum and average values from climate models, Build. Serv. Eng. Res. Technol., 28, 237-248, https://doi.org/10.1177/0143624407078642, 2007.

Colbeck, S. C.: A theory of water percolation in snow, J. Glaciol., 11, 369-385, 1972.

Connon, R. F., Quinton, W. L., Craig, J. R., and Hayashi, M.: Changing hydrologic connectivity due to permafrost thaw in the lower Liard River valley, NWT, Canada, Hydrol. Process., 28, 4163-4178, https://doi.org/10.1002/hyp.10206, 2014.

DeBeer, C. M., Wheater, H. S., Carey, S. K., and Chun, K. P.: Recent climatic, cryospheric, and hydrological changes over the interior of western Canada: A review and synthesis, Hydrol. Earth Syst. Sci., 20, 1573-1598, https://doi.org/10.5194/hess-20-1573-2016, 2016.

Dee, D. P., Uppala, S. M., Simmons, A. J., Berrisford, P., Poli, P., Kobayashi, S., Andrae, U., Balmaseda, M. A., Balsamo, G., Bauer, P., Bechtold, P., Beljaars, A. C. M., van de Berg, L., Bidlot, J., Bormann, N., Delsol, C., Dragani, R., Fuentes, M., Geer, A. J., Haimberger, L., Healy, S. B., Hersbach, H., Hólm, E. V., Isaksen, L., Kållberg, P., Köhler, M., Matricardi, M., McNally, A. P., Monge-Sanz, B. M., Morcrette, J.-J., Park, B.-K., Peubey, C., de Rosnay, P., Tavolato, C., Thépaut, J.-N., and Vitart, F.: The ERA-Interim reanalysis: configuration and performance of the data assimilation system, Q. J. Roy. Meteorol. Soc., 137, 553597, https://doi.org/10.1002/qj.828, 2011.

Déry, S. J. and Wood, E. F.: Teleconnection between the Arctic Oscillation and Hudson Bay river discharge, Geophys. Res. Lett., 31, 2-5, https://doi.org/10.1029/2004GL020729, 2004.
Ellis, C. R., Pomeroy, J. W., and Link, T. E.: Modeling increases in snowmelt yield and desynchronization resulting from forest gap-thinning treatments in a northern mountain headwater basin, Water Resour. Res., 49, 936-949, https://doi.org/10.1002/wrcr.20089, 2013.

Essery, R. L. H. and Pomeroy, J. W.: Vegetation and Topographic Control of Wind-Blown Snow Distributions in Distributed and Aggregated Simulations for an Arctic Tundra Basin, J. Hydrometeorol., 5, 735-744, https://doi.org/10.1175/15257541(2004)005<0735:VATCOW>2.0.CO;2, 2004.

Flügel, W.-A.: Delineating hydrological response units by geographycal information system analyses for regional hydrological modelling using PRMS/MMS in the drainage basin of the River Bröl, Germany, Hydrol. Process., 9, 423-436, 1995.

Goodison, B. E., Louie, P. Y., and Yang, D.: WMO Solid Precipitation Measurement Intercomparison, Report No. 67, World Meteorological Organization, available at: http://www.wmo.int/pages/ prog/www/reports/WMOtd872.pdf (last access: 12 July 2018), 1998.

Gray, D. M., Toth, B., Zhao, L., Pomeroy, J. W., and Granger, R. J.: Estimating areal snowmelt infiltration into frozen soils, Hydrol. Process., 15, 3095-3111, https://doi.org/10.1002/hyp.320, 2001.

Güntner, A., Olsson, J., Calver, A., and Gannon, B.: Cascadebased disaggregation of continuous rainfall time series: the influence of climate, Hydrol. Earth Syst. Sci., 5, 145-164, https://doi.org/10.5194/hess-5-145-2001, 2001.

Hamed, K. H.: Trend detection in hydrologic data: The MannKendall trend test under the scaling hypothesis, J. Hydrol., 349, 350-363, https://doi.org/10.1016/j.jhydrol.2007.11.009, 2008.

Hamed, K. H. and Rao, A. R.: A modified Mann-Kendall trend test for autocorrelated data, J. Hydrol., 204, 182-196, https://doi.org/10.1016/S0022-1694(97)00125-X, 1998.

Hansen, J., Ruedy, R., Sato, M., and Lo, K.: Global surface temperature change, Rev. Geophys., 48, RG4004, https://doi.org/10.1029/2010RG000345, 2010.

Hedstrom, N. R. and Pomeroy, J. W.: Measurements and modelling of snow interception in the boreal forest, Hydrol. Process., 12, 1611-1625, https://doi.org/10.1002/(SICI)10991085(199808/09)12:10/11<1611::AID-HYP684>3.0.CO;2-4, 1998.

Hess, A., Iyer, H., and Malm, W.: Linear trend analysis: a comparison of methods, Atmos. Environ., 35, 5211-5222, https://doi.org/10.1016/S1352-2310(01)00342-9, 2001.

Hinkley, D. V: Inference About the Change-Point in a Sequence of Random Variables, Biometrika, 57, 1-17, https://doi.org/10.2307/2334932, 1970.

Hinzman, L. D., Bettez, N. D., Bolton, W. R., Chapin, F. S., Dyurgerov, M. B., Fastie, C. L., Griffith, B., Hollister, R. D., Hope, A., Huntington, H. P., Jensen, A. M., Jia, G. J., Jorgenson, T., Kane, D. L., Klein, D. R., Kofinas, G., Lynch, A. H., Lloyd, A. H., McGuire, A. D., Nelson, F. E., Oechel, W. C., Osterkamp, T. E., Racine, C. H., Romanovsky, V. E., Stone, R. S., Stow, D. A., Sturm, M., Tweedie, C. E., Vourlitis, G. L., Walker, M. D., Walker, D. A., Webber, P. J., Welker, J. M., Winker, K. S., and Yoshikawa, K.: Evidence and Implications of Recent Climate Change in Northern Alaska and Other Arctic Regions, Climatic Change, 72, 251-298, https://doi.org/10.1007/s10584-005-53522,2005 . 
Hurrell, J. W., Kushnir, Y., and Visbeck, M. H.: The North Atlantic Oscillation, Science, 291, 603-605, https://doi.org/10.1126/science.1058761, 2001.

Janowicz, J. R.: Observed trends in the river ice regimes of northwest Canada, Hydrol. Res., 41, 462-470, https://doi.org/10.2166/nh.2010.145, 2010.

Ju, J. and Masek, J. G.: The vegetation greenness trend in Canada and US Alaska from 1984-2012 Landsat data, Remote Sens. Environ., 176, 1-16, https://doi.org/10.1016/j.rse.2016.01.001, 2016

Juminikis, A. R.: Thermal Geotechnics, Rutgers University Press, New Brunswick, New Jersey, 1977.

Kane, D. L.: Snowmelt infiltration into seasonally frozen soils, Cold Reg. Sci. Technol., 3, 153-161, https://doi.org/10.1016/0165232X(80)90020-8, 1980.

Kane, D. L. and Stein, J.: Water movement into seasonally frozen soils, Water Resour. Res., 19, 1547-1557, https://doi.org/10.1029/WR019i006p01547, 1983.

Kane, D. L., Hinzman, L. D., Benson, C. S., and Liston, G. E.: Snow hydrology of a headwater arctic basin, 1. Physical measurements and process studies, Water Resour. Res., 27, 10991109, https://doi.org/10.1029/91WR00262, 1991.

Kendall, M. G.: Rank Correlation Methods, Griffin, London, 1975.

Killick, R., Haynes, K., Eckley, I., Fearnhead, P., and Lee, J.: Methods for Changepoint Detection, available at: https: //cran.r-project.org/web/packages/changepoint/changepoint.pdf (last access: 12 July 2018), 2016.

Krogh, S. A., Pomeroy, J. W., and McPhee, J.: Physically Based Mountain Hydrological Modeling Using Reanalysis Data in Patagonia, J. Hydrometeorol., 16, 172-193, https://doi.org/10.1175/JHM-D-13-0178.1, 2015.

Krogh, S. A., Pomeroy, J. W., and Marsh, P.: Diagnosis of the hydrology of a small Arctic basin at the tundra-taiga transition using a physically based hydrological model, J. Hydrol., 550, 685703, https://doi.org/10.1016/j.jhydrol.2017.05.042, 2017.

Lantz, T. C., Marsh, P., and Kokelj, S. V.: Recent Shrub Proliferation in the Mackenzie Delta Uplands and Microclimatic Implications, Ecosystems, 16, 47-59, https://doi.org/10.1007/s10021012-9595-2, 2013.

Laudon, H., Spence, C., Buttle, J., Carey, S. K., McDonnell, J. J., McNamara, J. P., Soulsby, C., and Tetzlaff, D.: Save northern high-latitude catchments, Nat. Geosci., 10, 324-325, https://doi.org/10.1038/ngeo2947, 2017.

Lawrence, M. G.: The relationship between relative humidity and the dewpoint temperature in moist air: A simple conversion and applications, B. Am. Meteorol. Soc., 86, 225-233, https://doi.org/10.1175/BAMS-86-2-225, 2005.

Liljedahl, A. K., Boike, J., Daanen, R. P., Fedorov, A. N., Frost, G. V., Grosse, G., Hinzman, L. D., Iijma, Y., Jorgenson, J. C., Matveyeva, N., Necsoiu, M., Raynolds, M. K., Romanovsky, V., Schulla, J., Tape, K. D., Walker, D. A., Wilson, C., Yabuki, H., and Zona, D.: Pan-Arctic ice-wedge degradation in warming permafrost and influence on tundra hydrology, Nat. Geosci., 9, 1-8, https://doi.org/10.1038/ngeo2674, 2016.

Lindsay, R., Wensnahan, M., Schweiger, A., and Zhang, J.: Evaluation of seven different atmospheric reanalysis products in the arctic, J. Climate, 27, 2588-2606, https://doi.org/10.1175/JCLID-13-00014.1, 2014
Liston, G. E. and Hiemstra, C. A.: The changing cryosphere: PanArctic snow trends (1979-2009), J. Climate, 24, 5691-5712, https://doi.org/10.1175/JCLI-D-11-00081.1, 2011.

López-Moreno, J. I., Pomeroy, J. W., Revuelto, J., and VicenteSerrano, S. M.: Response of snow processes to climate change: spatial variability in a small basin in the Spanish Pyrenees, Hydrol. Process., 27, 2637-2650, https://doi.org/10.1002/hyp.9408, 2012.

López-Moreno, J. I., Boike, J., Sanchez-Lorenzo, A., and Pomeroy, J. W.: Impact of climate warming on snow processes in Ny-Ålesund, a polar maritime site at Svalbard, Global Planet. Change, 146, 10-21, https://doi.org/10.1016/j.gloplacha.2016.09.006, 2016.

Mann, H. B.: Nonparametric Test against Trend, Econometrica, 13, 245-259, https://doi.org/10.2307/1907187, 1945.

Mantua, N. J. and Hare, S. R.: The Pacific Decadal Oscillation, J. Oceanogr., 58, 35-44, https://doi.org/10.1023/A:1015820616384, 2002.

Marsh, P. and Woo, M.-K.: Wetting front advance and freezing of meltwater within a snow cover: 1 . Observations in the Canadian Arctic, Water Resour. Res., 20, 1853-1864, https://doi.org/10.1029/WR020i012p01865, 1984a.

Marsh, P. and Woo, M.-K.: Wetting front advance and freezing of meltwater within a snow cover: 2. A simulation model, Water Resour. Res., 20, 1865-1874, https://doi.org/10.1029/WR020i012p01865, 1984b.

Marsh, P., Bartlett, P., MacKay, M., Pohl, S., and Lantz, T.: Snowmelt energetics at a shrub tundra site in the western Canadian Arctic, Hydrol. Process., 24, 3603-3620, https://doi.org/10.1002/hyp.7786, 2010.

Martin, A. C., Jeffers, E. S., Petrokofsky, G., Myers-Smith, I. H., and Macias-Fauria, M.: Shrub growth and expansion in the Arctic tundra: an assessment of controlling factors using an evidence-based approach, Environ. Res. Lett., 12, 085007, https://doi.org/10.1088/1748-9326/aa7989, 2017.

McClelland, J. W., Déry, S. J., Peterson, B. J., Holmes, R. M., and Wood, E. F.: A pan-arctic evaluation of changes in river discharge during the latter half of the 20th century, Geophys. Res. Lett., 33, 2-5, https://doi.org/10.1029/2006GL025753, 2006.

Mekis, É. and Vincent, L. A.: An Overview of the Second Generation Adjusted Daily Precipitation Dataset for Trend Analysis in Canada, Atmosphere-Ocean, 49, 163-177, https://doi.org/10.1080/07055900.2011.583910, 2011.

Ménard, C. B., Essery, R., Pomeroy, J., Marsh, P. and Clark, D. B.: A shrub bending model to calculate the albedo of shrub-tundra, Hydrol. Process., 28, 341-351, https://doi.org/10.1002/hyp.9582, 2012.

Ménard, C. B., Essery, R., and Pomeroy, J. W.: Modelled sensitivity of the snow regime to topography, shrub fraction and shrub height, Hydrol. Earth Syst. Sci., 18, 2375-2392, https://doi.org/10.5194/hess-18-2375-2014, 2014.

Milewska, E. and Hogg, W. D.: Spatial representativeness of a longterm climate network in Canada, Atmosphere-Ocean, 39, 145161, https://doi.org/10.1080/07055900.2001.9649671, 2001.

Musselman, K. N., Clark, M. P., Liu, C., Ikeda, K., and Rasmussen, R.: Slower snowmelt in a warmer world, Nat. Clim. Change, 7, 214-219, https://doi.org/10.1038/nclimate3225, 2017. 
Myers-Smith, I. H. and Hik, D. S.: Climate warming as a driver of tundra shrubline advance, J. Ecol., 106, 547-560, https://doi.org/10.1111/1365-2745.12817, 2018.

Myers-Smith, I. H., Forbes, B. C., Wilmking, M., Hallinger, M., Lantz, T., Blok, D., Tape, K. D., Macias-Fauria, M., SassKlaassen, U., Lévesque, E., Boudreau, S., Ropars, P., Hermanutz, L., Trant, A., Collier, L. S., Weijers, S., Rozema, J., Rayback, S. A., Schmidt, N. M., Schaepman-Strub, G., Wipf, S., Rixen, C., Ménard, C. B., Venn, S., Goetz, S., Andreu-Hayles, L., Elmendorf, S., Ravolainen, V., Welker, J., Grogan, P., Epstein, H. E., and Hik, D. S.: Shrub expansion in tundra ecosystems: dynamics, impacts and research priorities, Environ. Res. Lett., 6, 045509, https://doi.org/10.1088/1748-9326/6/4/045509, 2011.

Oelke, C., Zhang, T., and Serreze, M. C.: Modeling evidence for recent warming of the Arctic soil thermal regime, Geophys. Res. Lett., 31, 4-7, https://doi.org/10.1029/2003GL019300, 2004.

Ohmura, A.: Observed decadal variations in surface solar radiation and their causes, J. Geophys. Res., 114, D00D05, https://doi.org/10.1029/2008JD011290, 2009.

Overeem, I. and Syvitski, J. P. M.: Shifting Discharge Peaks in Arctic Rivers, 1977-2007, Geogr. Ann., 92, 285-296, https://doi.org/10.1111/j.1468-0459.2010.00395.x, 2010.

Pan, X., Yang, D., Li, Y., Barr, A., Helgason, W., Hayashi, M., Marsh, P., Pomeroy, J., and Janowicz, R. J.: Bias corrections of precipitation measurements across experimental sites in different ecoclimatic regions of western Canada, The Cryosphere, 10, 2347-2360, https://doi.org/10.5194/tc-10-2347-2016, 2016.

Payette, S. and Filion, L.: White spruce expansion at the tree line and recent climatic change, Can. J. Forest. Res., 15, 241-251, https://doi.org/10.1139/x85-042, 1985.

Peterson, B. J., Holmes, R. M., McClelland, J. W., Vorosmarty, C. J., Lammers, R., Shiklomanov, A. I., Shiklomanov, I. A., and Rahmstorf, S.: Increasing River Discharge to the Arctic Ocean, Science, 298, 2171-2173, https://doi.org/10.1126/science.1077445, 2002.

Pomeroy, J. W. and Brun, E.: Physical Properties of Snow, in: Snow Ecol. an Interdiscip. Exam. Snow-covered Ecosyst., chap. 2, edited by: Jones, H. G., Pomeroy, J. W., Walker, D. A., and Hoham, R. W., Cambridge University Press, New York, USA, 45-118, http://www.usask.ca/hydrology/papers/Pomeroy_et_al_ 2001.pdf (last access: 12 July 2018), 2001.

Pomeroy, J. W. and Goodison, B. E.: Winter and Snow, in: The Surface Climates of Canada, chap. 4, edited by: Bailey, W. G., Oke, T. R., and Rouse, W. R., McGill-Queen's University Press, Montreal, Kingston, Canada, 68-100, 1997.

Pomeroy, J. W. and Marsh, P.: The application of remote sensing and a blowing snow model to determine snow water equivalent over northern basins, in: Applications of remote sensing in hydrology: NHRI Symposium No. 17, edited by: Kite, G. W., Pietroniro, A., and Pultz, T. J., National Hydrology Research Institute, Environment Canada, Saskatoon, SK, 253-270, 1996.

Pomeroy, J. W., Marsh, P., and Gray, D. M.: Application of a distributed blowing snow model to the Arctic, Hydrol. Process., 11, 1451-1464, https://doi.org/10.1002/(SICI)10991085(199709)11:11<1451::AID-HYP449>3.0.CO;2-Q, 1997.

Pomeroy, J. W., Parviainen, J., Hedstrom, N., and Gray, D. M.: Coupled modelling of forest snow interception and sublimation, Hydrol. Process.,
12, 2317-2337, https://doi.org/10.1002/(SICI)1099 1085(199812)12:15<2317::AID-HYP799>3.0.CO;2-X, 1998.

Pomeroy, J. W., Bewley, D. S., Essery, R. L. H., Hedstrom, N. R., Link, T., Granger, R. J., Sicart, J. E., Ellis, C. R., and Janowicz, J. R.: Shrub tundra snowmelt, Hydrol. Process., 20, 923-941, https://doi.org/10.1002/hyp.6124, 2006.

Pomeroy, J. W., Fang, X., Shook, K., and Whitfield, P. H.: Predicting in Ungauged Basins using Physical Principles Obtained using The Deductive, Inductive, and Abductive Reasoning Approach, in: Putting Prediction in Ungauged Basins into Practice, Canadian Water Resources Association (CWRA) and the International Association of Hydrological Sciences (IAHS), Ottawa, 41-62, 2013a.

Pomeroy, J. W., Spence, C., Whitfield, P. H., and Spence, C.: Putting Prediction in Ungauged Basins into Practice, Canadian Water Resources Association, International Association of Hydrological Sciences, available at: https://cwra.org/ en/resource-center/publications/bookstore/20-publications/ 245-putting-prediction-in-ungauged-basins-into-practice (last access: 12 July 2018), 2013 b.

Pomeroy, J. W., Fang, X., and Rasouli, K.: Sensitivity of snow processes to warming in the Canadian Rockies, 72nd East. Snow Conf. Sherbrooke, Quebec, Canada, 22-33, 2015.

Prowse, T., Alfredsen, K., Beltaos, S., Bonsal, B., Duguay, C., Korhola, A., McNamara, J., Pienitz, R., Vincent, W. F., Vuglinsky, V., and Weyhenmeyer, G. A.: Past and future changes in Arctic lake and river ice, Ambio, 40, 53-62, https://doi.org/10.1007/s13280-011-0216-7, 2011.

Przybylak, R., Vízi, Z., and Wyszyński, P.: Air temperature changes in the Arctic from 1801 to 1920 , Int. J. Climatol., 30, 791-812, https://doi.org/10.1002/joc.1918, 2010.

Quinton, W. L. and Carey, S. K.: Towards an energy-based runoff generation theory for tundra landscapes, Hydrol. Process., 22, 4649-4653, https://doi.org/10.1002/hyp.7164, 2008.

Quinton, W. L. and Gray, D. M.: Estimating subsurface drainage from organic-covered hillslopes underlain by permafrost?: toward a combined heat and mass flux model, in: Sixth IAHS Scientific Assmble, Maastricht, the Netherlands, 2001.

Quinton, W. L. and Marsh, P.: A conceptual framework for runoff generation in a permafrost environment, Hydrol. Process., 13, 2563-2581, https://doi.org/10.1002/(SICI)10991085(199911)13:16<2563::AID-HYP942>3.0.CO;2-D, 1999.

Rapaic, M., Brown, R., Markovic, M., and Chaumont, D.: An Evaluation of Temperature and Precipitation Surface-Based and Reanalysis Datasets for the Canadian Arctic, 1950-2010, Atmosphere-Ocean, 42, 283-303, https://doi.org/10.1080/07055900.2015.1045825, 2015.

Rasmusson, E. M. and Carpenter, T. H.: Variations in Tropical Sea Surface Temperature and Surface Wind Fields Associated with the Southern Oscillation/El Niño, Mon. Weather Rev., 110, 354-384, https://doi.org/10.1175/15200493(1982)110<0354:VITSST>2.0.CO;2, 1982.

Rasouli, K., Pomeroy, J. W., Janowicz, J. R., Carey, S. K., and Williams, T. J.: Hydrological sensitivity of a northern mountain basin to climate change, Hydrol. Process., 28, 4191-5208, https://doi.org/10.1002/hyp.10244, 2014.

Rasouli, K., Pomeroy, J. W., and Marks, D. G.: Snowpack sensitivity to perturbed climate in a cool mid-latitude 
mountain catchment, Hydrol. Process., 29, 3925-3940, https://doi.org/10.1002/hyp.10587, 2015.

Romero-Lankao, P., Smith, J. B., Davidson, D. J., Diffenbaugh, N. S., Kinney, P. L., Kirshen, P., Kovacs, P., and Villers-Ruiz, L.: North America, in: Climate Change 2014: Impacts, Adaptation, and Vulnerability, Part B: Regional Aspects, Contribution of Working Group II to the Fifth Assessment Report of the Intergovernmental Panel of Climate Change, edited by: Barros, V. R., Field, C. B., Dokken, D. J., Mastrandrea, M. D., Mach, K. J., Bilir, T. E., Chatterjee, M., Ebi, K. L., Estrada, Y. O., Genova, R. C., Girma, B., Kissel, E. S., Levy, A. N., MacCracken, S., Mastrandrea, P. R., and White, L. L., Cambridge University Press, Cambridge, UK and New York, NY, USA, 1439-1498, 2014.

Rood, S. B., Kaluthota, S., Philipsen, L. J., Rood, N. J., and Zanewich, K. P.: Increasing discharge from the Mackenzie River system to the Arctic Ocean, Hydrol. Process., 31, 150-160, https://doi.org/10.1002/hyp.10986, 2017.

Saunders, R., Matricardi, M., and Brunel, P.: An improved fast radiative transfer model for assimilation of satellite radiance observations, Q. J. Roy. Meteorol. Soc., 125, 1407-1425, https://doi.org/10.1002/qj.1999.49712555615, 1999.

Schmidt, R. A.: Properties of blowing snow, Rev. Geophys., 20, 39 44, https://doi.org/10.1029/RG020i001p00039, 1982.

Schmidt, R. A. and Gluns, D. R.: Snowfall interception on branches of three conifer species, Can. J. Forest. Res., 21, 1262-1269, https://doi.org/10.1139/x91-176, 1991.

Sen, P. K.: Estimates of the regression coefficient based on Kendall's Tau, J. Am. Stat. Assoc., 63, 1379-1389, https://doi.org/10.2307/2285891, 1968.

Serreze, M. C. and Hurst, C. M.: Representation of Mean Arctic Precipitation from NCEP - NCAR and ERA Reanalyses, J. Climate, 13, 182-201, 2000.

Serreze, M. C., Key, J. R., Box, J. E., Maslanik, J. A., and Steffen, K.: A new monthly climatology of global radiation for the arctic and comparisons with NCEP-NCAR reanalysis and ISCCPC2 fields, J. Climate, 11, 121-136, https://doi.org/10.1175/15200442(1998)011<0121:ANMCOG>2.0.CO;2, 1998.

Serreze, M. C., Bromwich, D. H., Clark, M. P., Etringer, A. J., Zhang, T., and Lammers, R.: Large-scale hydro-climatology of the terrestrial Arctic drainage system, J. Geophys. Res., 108, 8160, https://doi.org/10.1029/2001JD000919, 2002.

Serreze, M. C., Clark, M. P., and Bromwich, D. H.: Monitoring Precipitation over the Arctic Terrestrial Drainage System?: Data Requirements, Shortcomings, and Applications of Atmospheric Reanalysis, J. Hydrometeorol., 4, 387-407, 2003.

Smith, C.: Correcting the wind bias in snowfall measurements made with a Geonor T-200B precipitation gauge and alter wind shield, in: CMOS Bulletin SCMO, vol. 36, Canadian Meteorological and Oceanographic Society (CMOS), Ottawa, Canada, 162-167, 2008.

Sturm, M., Racine, C., and Tape, K.: Increasing shrub abundance in the Arctic, Nature, 411, 456-457, 2001.

Sturm, M. E. A., Mcfadden, J. P., Liston, G. E., Chapin, F. S., Racine, C. H., and Holmgre, J.: Snow-Shrub Interactions in Arctic Tundra: A Hypothesis with Climatic Implications, J. Climate, 14, 336-344, 2000.

Suarez, F., Binkley, D., Kaye, M. W., and Stottlemyer, R.: Expansion of forest stands into tundra in the Noatak Na- tional Preserve, northwest Alaska, Ecoscience, 6, 465-470, https://doi.org/10.1080/11956860.1999.11682538, 1999.

Tape, K., Sturm, M., and Racine, C.: The evidence for shrub expansion in Northern Alaska and the Pan-Arctic, Global Chang. Biol., 12, 686-702, https://doi.org/10.1111/j.1365-2486.2006.01128.x, 2006.

Thompson, D. W. J. and Wallace, J. M.: The Arctic Oscillation signature in the wintertime geopotential height and temperature fields, Geophys. Res. Lett., 25, 1297, https://doi.org/10.1029/98GL00950, 1998.

Trenberth, K. E. and Hurrell, J. W.: Decadal atmosphereocean variations in the Pacific, Clim. Dynam., 9, 303-319, https://doi.org/10.1007/BF00204745, 1994.

Uppala, S. M., Kallberg, P. W., Simmons, A. J., Andrae, U., Bechtold, V. D. C., Fiorino, M., Gibson, J. K., Haseler, J., Hernandez, A., Kelly, G. A., Li, X., Onogi, K., Saarinen, S., Sokka, N., Allan, R. P., Andersson, E., Arpe, K., Balmaseda, M. A., Beljaars, A. C. M., Van De Berg, L., Bidlot, J., Bormann, N., Caires, S., Chevallier, F., Dethof, A., Dragosavac, M., Fisher, M., Fuentes, M., Hagemann, S., Hólm, E., Hoskins, B. J., Isaksen, L., Janssen, P. A. E. M., Jenne, R., Mcnally, a. P., Mahfouf, J.-F., Morcrette, J.-J., Rayner, N. A., Saunders, R. W., Simon, P., Sterl, A., Trenberth, K. E., Untch, A., Vasiljevic, D., Viterbo, P., and Woollen, J.: The ERA-40 re-analysis, Q. J. Roy. Meteorol. Soc., 131, 2961-3012, https://doi.org/10.1256/qj.04.176, 2005.

Vincent, L. A., Zhang, X., Brown, R. D., Feng, Y., Mekis, E., Milewska, E. J., Wan, H. and Wang, X. L.: Observed Trends in Canada's Climate and Influence of Low-Frequency Variability Modes, J. Climate, 28, 4545-4560, https://doi.org/10.1175/JCLID-14-00697.1, 2015.

Walsh, J. E.: Cryosphere and Hydrology, in: Arctic Climate Impact Assessment - Scientific Report, edited by: Symon, C., Arris, L., and Heal, B., Cambridge University Press, Cambridge, 183-242, 2005.

Walvoord, M. A. and Kurylyk, B. L.: Hydrologic impacts of thawing permafrost - a review, Vadose Zone J., 15, 1-20, https://doi.org/10.2136/vzj2016.01.0010, 2016.

Wanishsakpong, W., McNeil, N., and Notodiputro, K. A.: Trend and pattern classification of surface air temperature change in the Arctic region, Atmos. Sci. Lett., 17, 378-383, https://doi.org/10.1002/asl.668, 2016.

Wessel, D. A. and Rouse, W. R.: Modelling Evaporation From Wetland Tundra, Bound.-Lay. Meteorol., 41, 109-130, https://doi.org/10.1007/BF00712666, 1994.

Westerling, A. L., Hidalgo, H. G., Cayan, D. R., and Swetnam, T. W.: Warming and Earlier Spring Increase Western U.S. Forest Wildfire Activity, Science, 313, 940-943, https://doi.org/10.1126/science.1128834, 2006.

Weston, S. T., Bailey, W. G., McArthur, L. J. B., and Hertzman, O.: Interannual solar and net radiation trends in the Canadian Arctic, J. Geophys. Res.-Atmos., 112, 1-8, https://doi.org/10.1029/2006JD008000, 2007.

Whitfield, P. H., Hall, A. W., and Cannon, A. J.: Changes in the seasonal cycle in the circumpolar Arctic, 1976-95: temperature and precipitation, Arctic, 57, 80-93, 2004.

Williamson, T., Colombo, S., Duinker, P., Gray, P., Hennessey, R., Houle, D., Johnston, M., Ogden, A., and Spittlehouse, D.: Climate change and Canada's forests: from impacts to adaptation, Sustainable Forest Management Network and Natural Resources 
Canada, Canadian Forest Service, Northern Forestry Centre, Edmonton, AB, 2009.

Woo, M.-K. and Sauriol, J.: Channel Development in Snow-Filled Valleys, Resolute, N.W.T., Canada, Geogr. Ann., 62, 37-56, 1980.

Woo, M.-K., Kane, D. L., Carey, S. K., and Yang, D.: Progress in permafrost hydrology in the new millennium, Permafrost Periglac. Process., 19, 237-254, https://doi.org/10.1002/ppp.613, 2008.

Xu, L., Myneni, R. B., Chapin III, F. S., Callaghan, T. V., Pinzon, J. E., Tucker, C. J., Zhu, Z., Bi, J., Ciais, P., Tømmervik, H., Euskirchen, E. S., Forbes, B. C., Piao, S. L., Anderson, B. T., Ganguly, S., Nemani, R. R., Goetz, S. J., Beck, P. S. A., Bunn, A. G., Cao, C., and Stroeve, J. C.: Temperature and vegetation seasonality diminishment over northern lands, Nat. Clim. Change, 6, 581-586, https://doi.org/10.1038/nclimate1836, 2013.
Yang, D., Kane, D. L., Hinzman, L. D., Zhang, X., Zhang, T., and Ye, H.: Siberian Lena River hydrologic regime and recent change, J. Geophys. Res.-Atmos., 107, 1-10, https://doi.org/10.1029/2002JD002542, 2002.

Yip, Q. K. Y., Burn, D. H., Seglenieks, F., Pietroniro, A., and Soulis, E. D.: Climate Impacts on Hydrological Variables in the Mackenzie River Basin, Can. Water Resour. J., 37, 209-230, https://doi.org/10.4296/cwrj2011-899, 2012.

Zhang, Z., Kane, D. L., and Hinzman, L. D.: Development and application of a spatially-distributed Arctic hydrological and thermal process model (ARHYTHM), Hydrol. Process., 14, 1017-1044, https://doi.org/10.1002/(SICI)10991085(20000430)14:6<1017::AID-HYP982>3.0.CO;2-G, 2000. 